\title{
Article \\ Adsorption Characteristics and Molecular Simulation of Malachite Green onto Modified Distillers' Grains
}

\author{
Chengtao Li ${ }^{1, *}$, Deyi Kong ${ }^{1}$, Xiaolong Yao ${ }^{2, *}$, Xiaotao Ma ${ }^{1}$, Chunhui Wei ${ }^{3}$ and Hong Wang ${ }^{4}$ \\ 1 College of Environmental Science and Engineering, Shaanxi University of Science \& Technology, \\ Xi'an 710021, China; kdy2929491809@163.com (D.K.); hanjhjh@163.com (X.M.) \\ 2 Key Laboratory of Cleaner Production and Integrated Resource Utilization of China National \\ Light Industry, Beijing Technology and Business University, Beijing 100048, China \\ 3 Liquor Making Biological Technology and Application of Key Laboratory of Sichuan Province, \\ Sichuan University of Science \& Engineering, Zigong 643000, China; wei_chunhui@suse.edu.cn \\ 4 Key Laboratory of Wuliangye-flavor Liquor Solid-state Fermentation, China National Light Industry, \\ Yibin 644000, China; wanghong@wuliangye.com.cn \\ * Correspondence: lct515@163.com (C.L.); yaoxiaolong@btbu.edu.cn (X.Y.)
}

check for updates

Citation: Li, C.; Kong, D.; Yao, X.; Ma, X.; Wei, C.; Wang, H. Adsorption Characteristics and Molecular Simulation of Malachite Green onto Modified Distillers' Grains. Water 2022, 14, 171. https://doi.org/ 10.3390/w14020171

Academic Editor: Laura Bulgariu

Received: 8 December 2021

Accepted: 6 January 2022

Published: 8 January 2022

Publisher's Note: MDPI stays neutral with regard to jurisdictional claims in published maps and institutional affiliations.

Copyright: (C) 2022 by the authors. Licensee MDPI, Basel, Switzerland. This article is an open access article distributed under the terms and conditions of the Creative Commons Attribution (CC BY) license (https:// creativecommons.org/licenses/by/ $4.0 /)$.

\begin{abstract}
Adsorbent material was prepared using distillers' grains (DG), which is a waste product of distilleries. The DG was pre-treated with $\mathrm{NaOH}$ and esterification-modified with CS2, which is a commonly used anionic modifier. The structure and morphology of the adsorbent was characterized by FTIR, XRD, EDS, SEM, BET, and zeta potential. The related mechanism of adsorption of malachite green (MG) onto modified distiller's grains (MDG) was studied by adsorption experiments and molecular simulation techniques. The experimental results showed that CS2 successfully modified the DG fiber, and simultaneously yielded the MDG with a uniform pore distribution. MDG had a considerable adsorption capacity of $367.39 \mathrm{mg} / \mathrm{g}$ and a maximum removal rate of $96.51 \%$. After eight adsorption-desorption cycle experiments, the adsorption removal rate of MDG to MG dye remained at $82.6 \%$. The adsorption process could be fitted well by a pseudo-second-order kinetic model (the correlation coefficient R2 > 0.998) and Freundlich isotherm adsorption equation (the correlation coefficient R2 > 0.972). Moreover, the adsorption of MG dye by MDG is a spontaneous, endothermic, and increased entropy process. The results of molecular simulation showed that the mechanism of MG molecules onto MDG was mainly chemical adsorption. The adsorption performance of MG onto MDG was better and more stable than DG. Molecular simulation also provided a theoretical guidance of MDG adsorption-desorption for the research on recycling of DG resources.
\end{abstract}

Keywords: distiller's grain; cellulose modification; malachite green; adsorption; molecular simulation

\section{Introduction}

Distillers' grains (DG) are residues obtained from the solid-state distillation and brewing processes of fermented grains, usually generated due to incomplete fermentation. Various chemical macromolecules are present in DG, including proteins (26.8-33.7\%, dry weight basis), carbohydrates (39.2-61.9\%, including fibers), oils (3.5-12.8\%), and ash (2.0-9.8\%) [1]. The average annual output of DG in China is over 100 million tons [2]. DG waste discharged without proper treatment can cause rotting, and therefore causes serious pollution in environment. At present, most DG is used in applications such as cultivating edible mushrooms, producing fodder, and generating biogas, which have low utilization levels and low added value. Moreover, the abundant residual fiber and other components in DG cannot be reasonably utilized, resulting in a huge waste of resource and environmental pollution. Thus, it is necessary to develop a suitable utilization method for DG in line with the goals of the present century of carrying out clean production, developing sustainable agriculture and building a resource-saving society for sustainable development.

Malachite green (MG), also known as alkaline green, is a triphenylmethane-type dye [3]. It is easily soluble in water. It turns blue-green after dissolution in water and the 
aqueous solution becomes alkaline. As a typical cationic dye, MG is widely used in the leather, ceramics, textile and printing, and dyeing industries. Due to the benzene ring in its triphenylmethane structure, MG has a higher reactivity [4] and is difficult to degrade. More seriously, the dye accumulates in organisms and leads to carcinogenic, teratogenic, and mutagenic risks [5,6]. The main treatment methods for MG wastewater include the electrochemical method [7], the flocculation method, membrane separation, microwave degradation, and the adsorption method [8,9]. Among these methods, the adsorption method is simple and has a relatively low cost, therefore this method can be used for the treatment of wastewater from printing and dyeing industry. Currently, some new, high-efficient, and inexpensive adsorbent materials with high surface area, including saw dust [10], orange peel [11], activated carbon [12], peanut shell [13], and bagasse [14] have been developed and utilized as new adsorption material for organic dyes [15-20]). The dual function adsorbent (IPNs) showed an excellent CV dye adsorption capacity (94.4\%, $\mathrm{Q}_{\max }=555.6 \mathrm{mg} / \mathrm{g}$ ) at the optimum conditions chosen [21]. However, to the best of our knowledge, DG has not been applied yet as an adsorbent for organic dyes [22-25].

The protein, fat, and microbial precursors in DG can be removed via a suitable pretreatment method [26,27], which can lead to a large number of pores in the DG structure ultimately increasing its specific surface area [28]. Furthermore, a large number of active hydroxyl and carbonyl groups exists on the surface of DG fiber [29,30]. $\mathrm{CS}_{2}$ is a commonly used anionic modifier. Under alkaline conditions, $\mathrm{CS}_{2}$ reacts with $\mathrm{NaOH}$ to form dithiocarbonate $\left(\mathrm{HCS}_{2} \mathrm{ONa}\right)$, and then reacts with the hydroxyl group on cellulose structure to be esterified and form cellulose xanthogen acid sodium salt, and the resultant product is an intermediate, which can be decomposed easily. Metal ions need to be added for transformation to increase the stability of the product. Metal ions such as $\mathrm{Mg}^{2+}$ can form a more stable structure with $S$ and $O$ atoms in cellulose xanthogenate [29]. Therefore, DG fibers can easily form modified distiller's grains (MDG) via chemical modification and react with the cationic groups of MG, which can further enhance the adsorption performance of distillers' grains.

However, in the existing studies, the adsorption efficiency and adsorption capacity of MDG are not very high, and is only used once, without multiple cycles of adsorption. If it can be reused many times, its resource utilization rate will be greatly improved.

In this study, DG fiber was used as raw material to prepare MDG through pretreatment and chemical modification. The structure and composition of DG before and after modification was characterized by FTIR, XRD, EDS, BET, and SEM. The adsorption mechanism of DG for MG was discussed through the adsorption kinetic equation, the adsorption isothermal equation, and the thermodynamic equations and molecular simulation of adsorption process. The present work can provide a reference for the high value-added comprehensive utilization of DG as a waste product of distilleries. This work also provides a method for the disposal of wastewater containing triphenylmethane-type dyes using the concept of "disposing waste with waste".

\section{Experimental Section}

\subsection{Reagents, Materials and Instrumentation}

Sodium hydroxide $(\mathrm{NaOH})$ and hydrochloric acid $(\mathrm{HCl})$ were purchased from Jinwang Chemical Co., Ltd. (Guangzhou, China), carbon disulfide $\left(\mathrm{CS}_{2}\right)$ and magnesium chloride $\left(\mathrm{MgCl}_{2}\right)$ were purchased from Yatai United Chemical Co., Ltd. (Wuxi, China), malachite green (MG) was purchased from Fuqiang Chemical Instrument Co., Ltd. (Hangzhou, China), and ethanol $\left(\mathrm{CH}_{3} \mathrm{CH}_{2} \mathrm{OH}\right)$ was purchased from Lu's Chemical Co., Ltd. (Shanghai, China). DG was procured from a winery in Xi'an, China. Distilled water was used for this experiment. The equipment used in this experiment includes a shredder (XS-10, Xunzhong, China), a constant temperature oscillator (OS-1102, Woxin, China), an ultraviolet-visible spectrophotometer (UV-2006A, Long Nike, China), a Fourier transform infrared spectroscopy (Vector-22, Bruker, Germany), scanning electron spectrometer (EDAX Octane Prime, EDAX, Mahwah, NJ, USA), advance X-ray diffractometer (AXS D8, Bruker, Ger- 
many), specific surface analyzer (ASAP2460, Mike Corporation, Norcross, GA, USA), and a scanning electron microscope (FEI-Q45, FEI, Hillsboro, OR, USA).

\subsection{Preparation of $M D G$}

To prepare the adsorbent, $15 \mathrm{~g}$ of 120 mesh DG powder was poured into a three-necked flask $(250 \mathrm{~mL})$, and then $200 \mathrm{~mL}$ of $10 \% \mathrm{NaOH}$ was added. The mixture was stirred at $110 \mathrm{rpm}$ at $30{ }^{\circ} \mathrm{C}$ for $3 \mathrm{~h}$ in a water bath. At the end of the reaction, distilled water and $95 \%$ ethanol solution were used to wash the mixture until it attained neutral $\mathrm{pH}$. Then the product was dried at $60{ }^{\circ} \mathrm{C}$ using an oven to obtain alkali DG fiber. Then, $10 \mathrm{~g}$ of DG alkali was placed in a $250 \mathrm{~mL}$ three-necked flask and $200 \mathrm{~mL}$ of $5 \% \mathrm{NaOH}$ was added. The mixture was stirred at $110 \mathrm{rpm}$ and allowed to react for $0.5 \mathrm{~h}$ in a water bath at $30{ }^{\circ} \mathrm{C}$. Next, $20 \mathrm{~g}$ of CS2 was added and the reaction was continued for $2.5 \mathrm{~h}$. Subsequently, $20 \mathrm{~mL}$ of $5 \%$ $\mathrm{MgCl} 2$ solution was added, and the reaction completed after $0.5 \mathrm{~h}$. Distilled water and 95\% ethanol solution were used to wash the mixture until it attained neutral $\mathrm{pH}$, and then the product was dried at $60{ }^{\circ} \mathrm{C}$ using an oven to obtain modified distiller's grains (MDG). The obtained MDG was sealed for later study, MDG The preparation scheme [29] is shown in Figure 1.
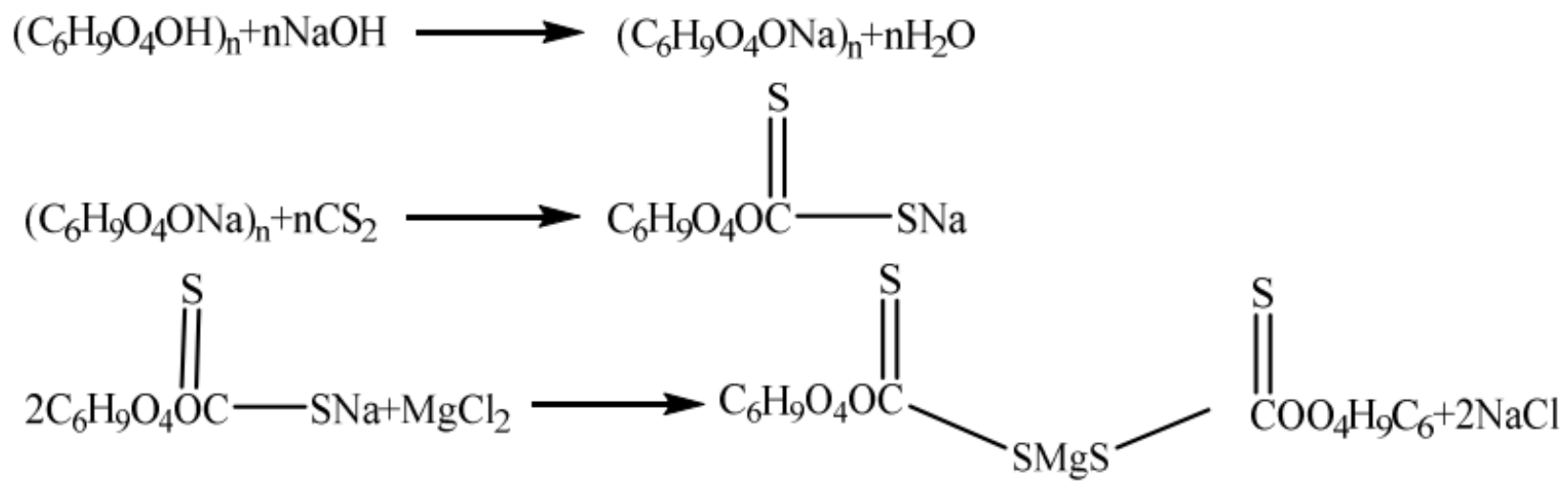

Figure 1. The preparation of MDG.

\subsection{Characterization of $M D G$}

The structure of the MDG was characterized using FTIR spectrometer with a scanning range of $4000 \sim 500 \mathrm{~cm}^{-1}$ and a scanning number of 32, the surface morphology of adsorption material was analyzed with FEI Q45 scanning electron microscope, the elemental composition of adsorbent was characterized by EDS, and the BT method was used to measure the surface area and pore structure of DG and MDG. The absorbance of MG-containing wastewater was measured with UV-Vis spectrophotometer.

\subsection{Adsorption Experiment}

For this experiment, $0.195 \mathrm{~g}$ of 140 mesh MDG was added to $30 \mathrm{~mL}$ of MG solution at the concentration of $200 \mathrm{mg} / \mathrm{L}$ for adsorption experiment. After the adsorption process, ultra-centrifugation of the mixture was done at $6000 \mathrm{r} / \mathrm{min}$ to get the supernatant. Absorbance of the MG remaining in the supernatant was recorded at $620 \mathrm{~nm}$. The following equations were used for calculating adsorption capacity and removal rate of DG for MG [30]:

$$
\begin{gathered}
\mathrm{q}_{\mathrm{e}}=\frac{\left(\mathrm{C}_{0}-\mathrm{C}_{\mathrm{e}}\right) \times \mathrm{V}}{m} \\
\eta=\frac{\mathrm{C}_{0}-\mathrm{C}_{\mathrm{e}}}{\mathrm{C}_{0}} \times 100 \%
\end{gathered}
$$

where:

$\mathrm{C}_{0}$ is the initial concentration; 
$\mathrm{C}_{\mathrm{e}}(\mathrm{mg} / \mathrm{L})$ is the final concentration of $\mathrm{MG}$ solution;

$\mathrm{V}(\mathrm{L})$ is the initial volume of MG solution;

$\mathrm{m}(\mathrm{g})$ is the absorbent mass;

$\mathrm{Q}_{\mathrm{e}}(\mathrm{mg} / \mathrm{g})$ is the adsorption capacity;

$\eta$ is the rate of removal.

\subsection{MDG Regeneration Performance}

Next, $0.15 \mathrm{~g}$ MDG was added to a $30 \mathrm{~mL}$ solution with an MG concentration of $200 \mathrm{mg} / \mathrm{L}$. After adsorption equilibrium, adsorbed MDG was added to $0.3 \mathrm{M} \mathrm{HCl}$ solution, shaken at $150 \mathrm{rpm}$ for $30 \mathrm{~min}$, washed with deionized water several times, and finally dried in a vacuum oven at $80^{\circ} \mathrm{C}$ to obtain regenerated MDG. After that, three parallel adsorption experiments were conducted to analyze the ability of the regenerated MDG to remove MG dye. To test the regeneration of CDG, the adsorption-desorption cycle was repeated eight times.

\subsection{Adsorption Kinetics}

The rate of change of adsorption capacity is explained by the adsorption kinetics. Pseudo-first-order, pseudo-second order and intra-particle diffusion models are commonly used to describe the solid-liquid adsorption kinetics. Equations (3)-(5) show pseudo-firstorder, pseudo-second order and intra-particle diffusion models, respectively:

$$
\begin{gathered}
\ln \left(\mathrm{q}_{\mathrm{e}}-\mathrm{q}_{\mathrm{t}}\right)=\ln \mathrm{q}_{\mathrm{e}}-\frac{\mathrm{k}_{1}}{2.303} \mathrm{t} \\
\frac{\mathrm{t}}{\mathrm{q}_{\mathrm{t}}}=\frac{1}{\mathrm{k}_{2} \mathrm{q}_{\mathrm{e}}^{2}}+\frac{\mathrm{t}}{\mathrm{q}_{\mathrm{e}}} \\
\mathrm{q}_{\mathrm{e}}=\mathrm{k}_{d} \mathrm{t}^{0.5}+\mathrm{C}
\end{gathered}
$$

where:

$\mathrm{q}_{\mathrm{e}}(\mathrm{mg} / \mathrm{g})$ shows the adsorption capacities at equilibrium;

$\mathrm{q}_{\mathrm{t}}(\mathrm{mg} / \mathrm{g})$ is the adsorption capacities at time $\mathrm{t}$;

$\mathrm{k}_{1}(\mathrm{~g} /(\mathrm{mg} / \mathrm{min})$ is the rate constant (pseudo-first order);

$\mathrm{k}_{2}$ ( $\mathrm{g} /(\mathrm{mg} / \mathrm{min})$ is the rate constant (pseudo-second order);

$\mathrm{k}_{\mathrm{d}}\left(\mathrm{mg} \mathrm{g}^{-1} \cdot \mathrm{min}^{-1 / 2}\right)$ is the intraparticle diffusion rate constant (intra-particle diffusion).

\subsection{Isotherm Model of Adsorption}

The Langmuir isotherm model assumes that: (a) molecular adsorption is a kind of mono-layer adsorption and a certain number of identical sites are distributed on a uniform surface, (b) the kinetic equilibrium cannot further adsorb except for the adsorption equilibrium, and (c) the adsorbed particles are thoroughly independent, and no interaction occurs between them [31,32]. The non-linear Langmuir isotherm equation is as follows:

$$
\mathrm{q}_{\mathrm{e}}=\frac{\mathrm{q}_{m} \mathrm{~K}_{\mathrm{L}} \mathrm{C}_{\mathrm{e}}}{1+\mathrm{K}_{\mathrm{L}} \mathrm{C}_{\mathrm{e}}}
$$

where:

$\mathrm{C}_{\mathrm{e}}(\mathrm{mg} / \mathrm{L})$ shows the equilibrium concentration;

$\mathrm{q}_{\mathrm{e}}(\mathrm{mg} / \mathrm{g})$ is the adsorption capacity at equilibrium concentration;

$\mathrm{q}_{\mathrm{m}}(\mathrm{mg} / \mathrm{g})$ is the saturated adsorption capacity;

$\mathrm{K}_{\mathrm{L}}(\mathrm{L} / \mathrm{mg})$ is the Langmuir adsorption constant related to adsorption capacity.

The Freundlich isotherm model is an empirical equation which can predict the situations where: (a) the surface of absorbent is non-uniform, (b) increase in concentration results in increased adsorption capacity, and (c) interaction amongst adsorbed molecules [33].:

$$
\mathrm{q}_{\mathrm{e}}=\mathrm{K}_{\mathrm{F}} \times \mathrm{C}_{\mathrm{e}}^{1 / \mathrm{nF}}
$$


where:

$\mathrm{C}_{\mathrm{e}}(\mathrm{mg} / \mathrm{L})$ is the equilibrium concentration;

$\mathrm{q}_{\mathrm{e}}(\mathrm{mg} / \mathrm{g})$ is the adsorption capacity at the equilibrium concentration;

$\mathrm{K}_{\mathrm{F}}(\mathrm{L} / \mathrm{mg})$ is the Freundlich adsorption constant which relates to adsorption capacity and characterized the strength of interaction between adsorbent and adsorbate. Adsorption capacity increases as the $\mathrm{K}_{\mathrm{F}}$ increase. The term $1 / \mathrm{n}$ is the heterogeneity factor of Freundlich isotherm, representing the adsorption intensity. When $0<1 / \mathrm{n}<1$, the adsorption is favorable and proceeds easily; if $1 / n=1$, the adsorption is non-linear and there is almost no interaction between adsorbent and adsorbate; when $1 / \mathrm{n}>1$, the adsorption is unfavorable and difficult.

The Temkin model is based on a linear relationship between the heat of adsorption and the temperature, rather than a logarithmic relationship. It can describe the purification mechanism well:

$$
\mathrm{q}_{\mathrm{e}}=\frac{\mathrm{RT}}{\beta_{\mathrm{T}}} \ln \left(\alpha_{\mathrm{T}} \mathrm{C}_{\mathrm{e}}\right)
$$

where:

$\mathrm{C}_{\mathrm{e}}(\mathrm{mg} / \mathrm{L})$ is the concentration of MG solution when the adsorbent reaches adsorption equilibrium;

$\mathrm{q}_{\mathrm{e}}(\mathrm{mg} / \mathrm{g})$ is the adsorption capacity at the equilibrium concentration;

$\alpha_{\mathrm{T}}(\mathrm{L} / \mathrm{mg}), \beta_{\mathrm{T}}(\mathrm{J} / \mathrm{mol})$ are the Temkin isothermal model parameters.

\subsection{Adsorption Thermodynamics}

The temperature effect on the adsorption process for the MG solution with different concentrations was studied. Relevant thermodynamic parameters [33] $\left(\Delta \mathrm{G}_{0}, \Delta \mathrm{S}_{0}, \Delta \mathrm{H}_{0}\right)$ were calculated using following equations:

$$
\begin{gathered}
\Delta \mathrm{G}_{0}=-\mathrm{RT} \operatorname{lnK} \\
\ln \mathrm{K}=\frac{\Delta \mathrm{S}_{0}}{\mathrm{R}}-\frac{\Delta \mathrm{H}_{0}}{\mathrm{RT}}
\end{gathered}
$$

where:

$\mathrm{T}$ is the temperature in Kelvin;

$\mathrm{R}$ is the universal gas constant;

$\mathrm{K}$ is the equilibrium constant $\left(\mathrm{K}=\mathrm{q}_{\mathrm{e}} / \mathrm{C}_{\mathrm{e}}\right)$;

$\mathrm{C}_{\mathrm{e}}(\mathrm{mg} / \mathrm{L})$ is the concentration at equilibrium;

$\mathrm{q}_{\mathrm{e}}(\mathrm{mg} / \mathrm{g})$ is the adsorption capacity at equilibrium.

\subsection{Molecular Simulation}

Materials Studio 7.0 (MS) software was used for model construction and molecular simulation study. The build module in MS is used to construct the unit cell of cellulose, which is a highly ordered polymer formed by direct combination of $1,4-\beta$-D-glucopyranose (Glc) [34]. Unit cell structure is as follows: $\mathrm{a}=7.784 \AA, \mathrm{b}=8.201 \AA, \mathrm{c}=10.38 \AA, \alpha=90^{\circ}$, $\beta=96.5^{\circ}, \gamma=90^{\circ}$. Using periodic boundary conditions, the basic unit is $2 \times 2 \times 2$ unit cells. The low energy surface $(-110)$ plane of the unit cell was intercepted as the adsorption surface model. The forcite module was then used for molecular dynamics optimization and was optimized to use a UFF force field. The evaluation function RMS $<0.001$ displays that the optimization was completed. The obtained unit cell configuration is shown in Figures 2 and 3. The unit cell size was a $=31.14 \AA, b=33.92 \AA, c=38.15 \AA$, degree of polymerization was 20 , and the resultant fiber was observed by TEM [35]. The prime unit cell was 3-4 nm. 


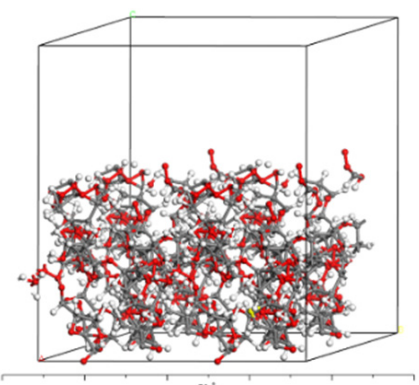

(a)

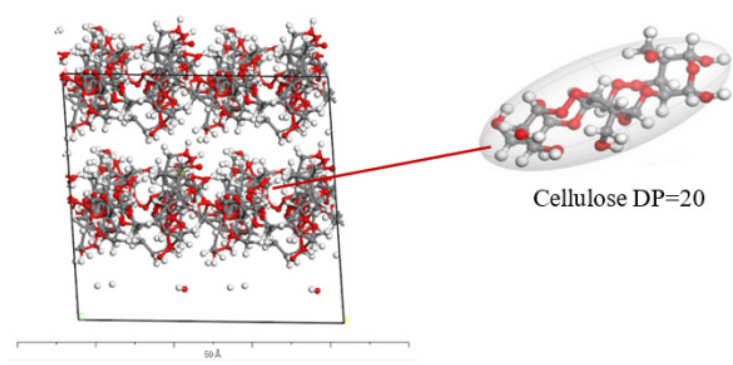

(b)

Figure 2. DG fiber ( $\left.\begin{array}{lll}-1 & 1 & 0\end{array}\right)$ surface optimized cell structure. (a) front view, (b) Top view.

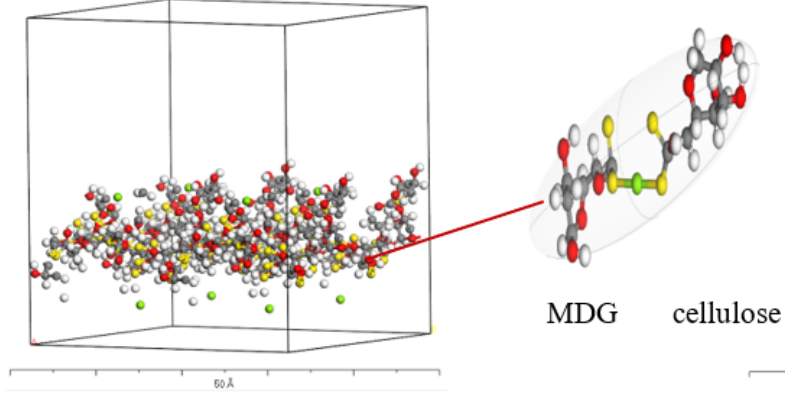

(a)

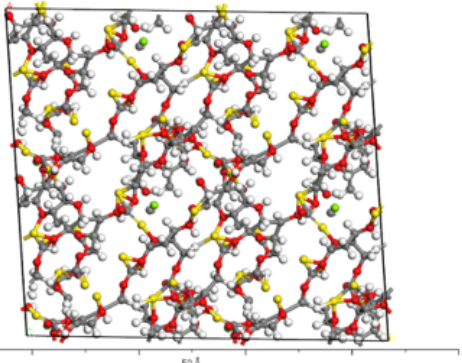

(b)

Figure 3. Cell structure of MDG fiber (-1 110$)$ surface optimization. (a) front view, (b) Top view.

The configuration of the MG molecule (MG) in Figure 4a and the MDG fiber (MDG) in Figure $4 \mathrm{~b}$ was minimized, and the force field was pcff. The optimized configuration is as follows:
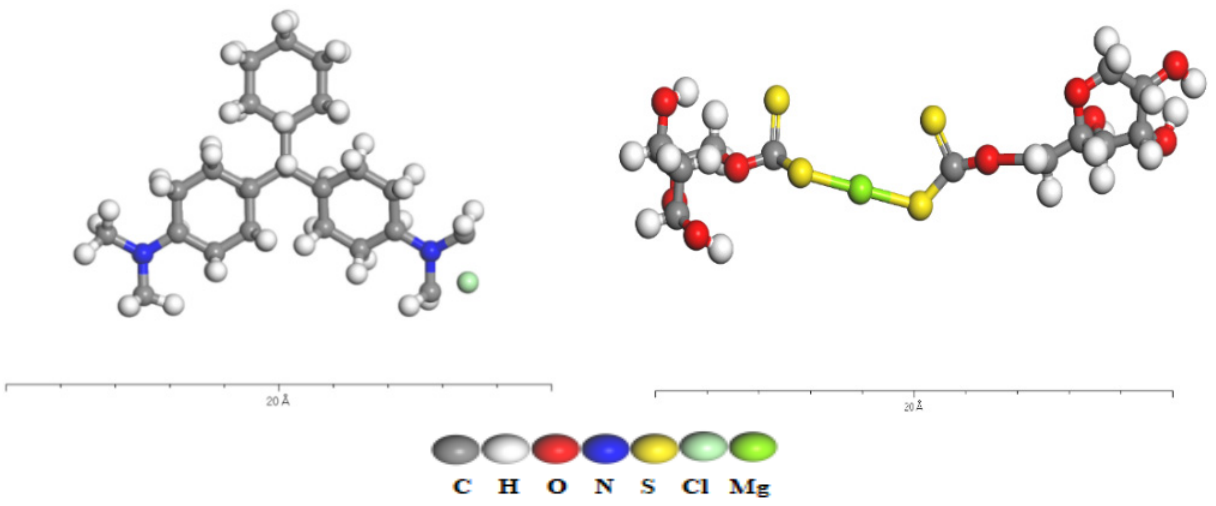

(a)Optimized MG molecules

(b) Optimized MDG fiber monomer

Figure 4. (a) MG molecules (b) MDG fiber optimized configuration.

The adsorption of MG molecules on the DG was carried out by the Metropolis Monte Carlo simulation method in sorption. To ensure the number of particles that appear and disappear during simulation were equal, the probability of particle exchange between two boxes was as follow: $39 \%$ interaction between molecules, molecular structure type change accounts for $20 \%$, molecular rotation accounts for $20 \%$, molecular translation accounts for $20 \%$, and molecular regeneration accounts for $2 \%$. The force field was UFF $[35,36]$. The Ewald summation method and atom-based method were used for electrostatic potential energy and van der Waals potential energy, respectively. The non-bond truncation distance 
was $12.5 \AA$, which was smaller than the minimum side length of the simulated unit cell (36.696 $\AA$ ) half. The number of steps was 10,000 , and the result was 100,000 steps.

\section{Results and Discussion}

\subsection{The DG and MDG Structures}

The FTIR spectra of DG and MDG are shown in Figure 5a. It shows that the stretching vibration absorption peaks of hydroxyl groups (-OH) of MDG at $3699 \mathrm{~cm}^{-1}$ and $3417 \mathrm{~cm}^{-1}$ were intensified [7]. An absorption peak at $1738 \mathrm{~cm}^{-1}$ corresponding to the stretching vibration of $-\mathrm{CH}_{2}$ - group disappeared while the stretching vibration peak of $-\mathrm{CH}_{2}$ - at $1632 \mathrm{~cm}^{-1}$ was intensified, indicating that there was a chemical reaction between DG, $\mathrm{NaOH}$, and $\mathrm{CS}_{2}$ after pre-treatment and chemical modification. The stretching vibration peak of the -C-O- group of MDG at $1090 \mathrm{~cm}^{-1}$ appears to be due to the sulfonation reaction between $\mathrm{CS}_{2}$ and the hydroxyl groups of DG fiber. Moreover, the absorption peaks of $-\mathrm{C}=\mathrm{S}$ and -C-S- at $1160 \mathrm{~cm}^{-1}$ and $1420 \mathrm{~cm}^{-1}$ appeared on the spectrum of MDG [37], which verifies the existence of $-\mathrm{O}-\mathrm{C}=\mathrm{S}$ functional group, and indicates that the $\mathrm{DG}$ fiber was successfully modified by $\mathrm{CS}_{2}$.
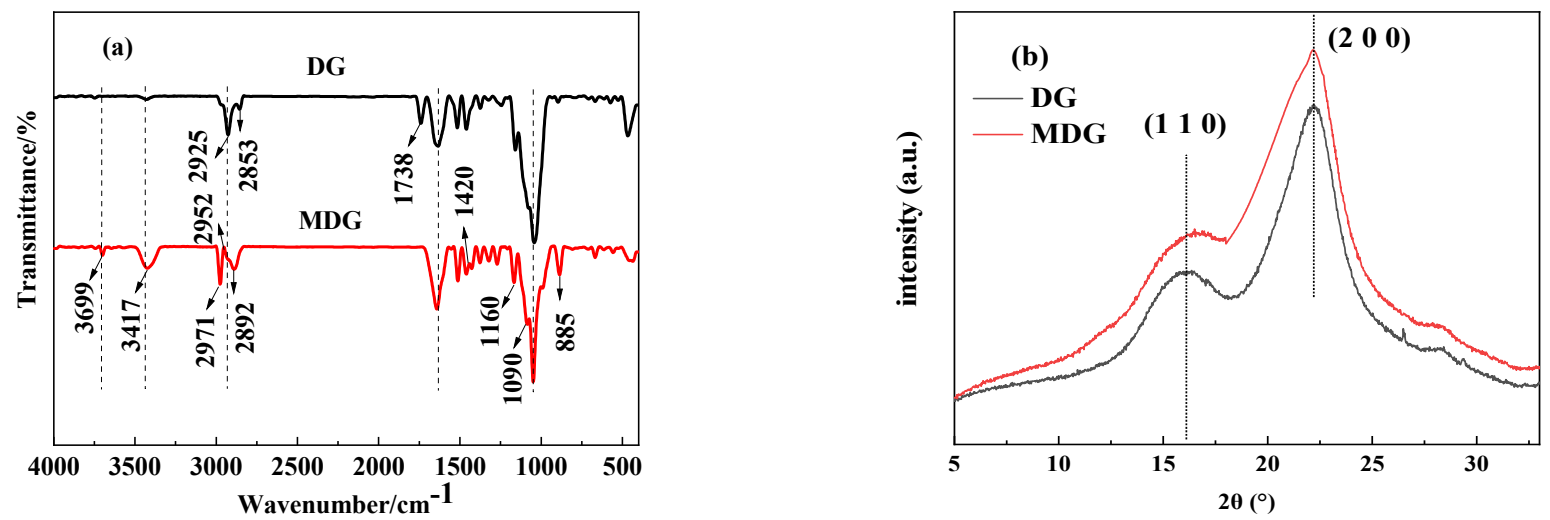

Figure 5. (a) FTIR spectra of DG and MDG (b) XRD patterns of DG and MDG.

Figure $5 \mathrm{~b}$ shows the XRD patterns of DG and MDG. It shows that DG exhibits two strong diffraction peaks at $16.1^{\circ}$ and $22.2^{\circ} 2 \theta$, corresponding to the crystal planes of $\left(\begin{array}{lll}1 & 1 & 0\end{array}\right)$ and (2 00$)$, respectively [38]. It indicates that the crystalline structure of cellulose in DG is cellulose $I \beta$. As shown in Figure 5b, MDG also exhibits two strong diffraction peaks at $16.1^{\circ}$ and $22.2^{\circ} 2 \theta$, which shows that the diffraction peaks of DG and MDG are the same. It indicates that chemical modification does not change the crystalline structure of cellulose.

Figure 6 shows the local point-scanning energy diagram of (a) DG and (b) MDG. The $\mathrm{C}$ and $\mathrm{O}$ contents of DG are $55.16 \%$ and $44.84 \%$, respectively (Figure $6 \mathrm{a}$ ). Figure $6 \mathrm{~b}$ shows that $\mathrm{Na}, \mathrm{Mg}$, and $\mathrm{S}$ elements are detected in the MDG. The elemental contents recorded are C $51.80 \%, \mathrm{O} 45.80 \%, \mathrm{Na} 0.45 \%, \mathrm{Mg} 1.59 \%$, and S $0.36 \%$, further indicating that the CS2 can successfully modify the DG fiber after the $\mathrm{NaOH}$ pre-treatment.

\subsection{Analyses of the Micro-Morphologies and Surface Structures of DG and MDG}

The micro-morphologies of (a) DG and (b) MDG were observed using SEM (Figure 7). It can be seen that the morphology of DG showed obvious change before and after the modification. Before modification, DG had a smooth, dense, and orderly surface. After the modification and pre-treatment, the lignin and fatty acids were removed, which increased the pores on the surface of MDG, causing the surface to become loose and porous [39]. This increased the surface area of adsorbent, which ultimately increased the adsorption mechanism for absorbate and helped the adsorption of MG. 

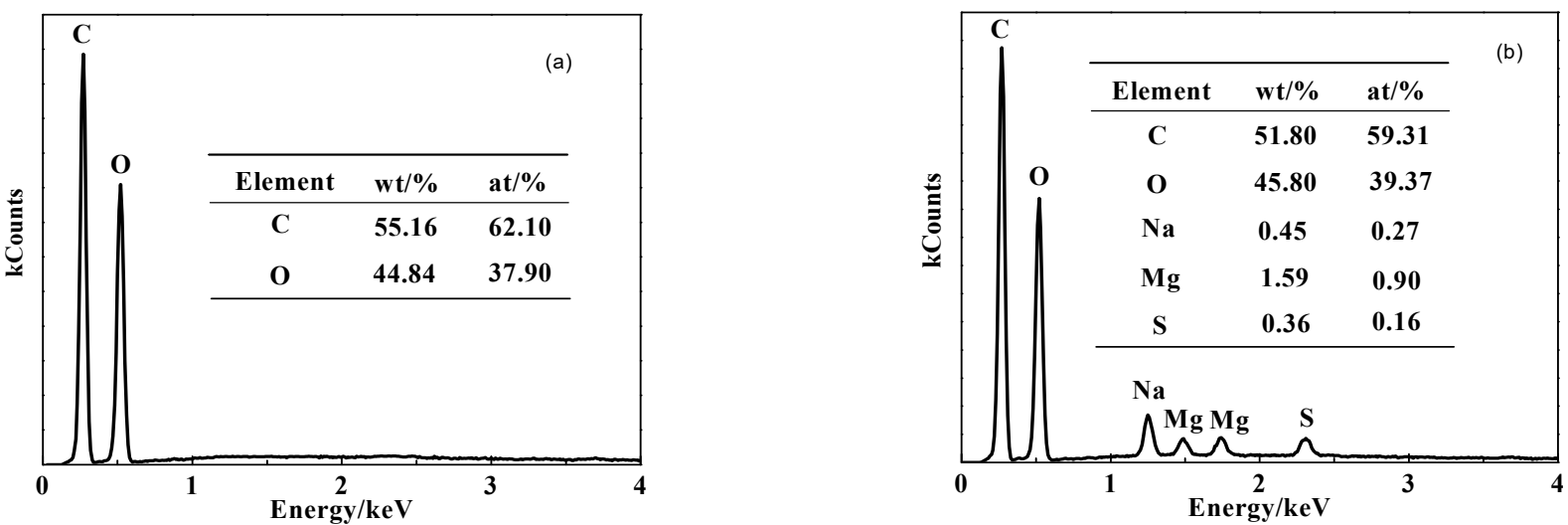

Figure 6. EDS images of (a) DG and (b) MDG.
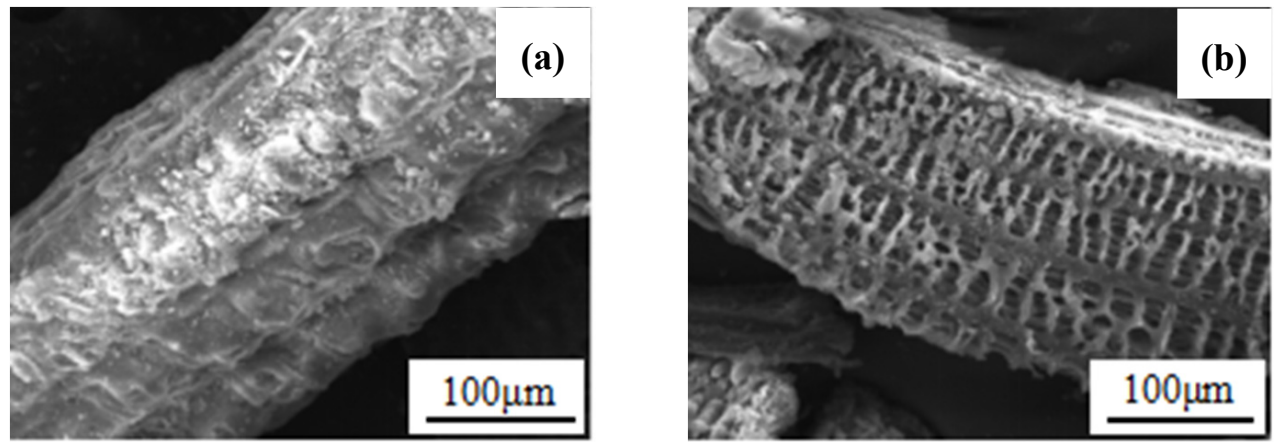

Figure 7. SEM images of (a) DG and (b) MDG.

Figure 8 represents the $\mathrm{N}_{2}$ adsorption-desorption curves and pore size distribution of DG and MDG. The $\mathrm{N}_{2}$ adsorption-desorption curves of the adsorbent, before and after modification, both belong to the typical type-IV curve (IUPAC classification) [40,41]. It can be seen from Figure 8a that the pore diameter of DG and MDG, both exhibited uniform size distributions which are between $5 \sim 100 \mathrm{~nm}$ and $10 \sim 40 \mathrm{~nm}$, respectively. When $\mathrm{P} / \mathrm{P}_{0}$ is less than or equal to 0.4 , the adsorption and desorption curves of MDG overlap each other, indicating the existence of micro-pores and mono-layer adsorption (Figure $8 \mathrm{~b}$ ). When $\mathrm{P} / \mathrm{P}_{0}$ was greater than 0.4 , the $\mathrm{N}_{2}$ adsorption capacity of MDG increased rapidly, indicating that the pores in the adsorbent were slit pores [42,43]. The surface area and pore volume of MDG increased significantly as compared to DG, which supports the results recorded in Table 1. The surface area of MDG was $3.54 \mathrm{~m}^{2} / \mathrm{g}$, showing an increase of $216 \%$ compared with DG.

Table 1. The pore structure parameters of DG and MDG.

\begin{tabular}{cccc}
\hline Sample & BET Surface Area $\left(\mathbf{m}^{2} / \mathbf{g}\right)$ & Pore Volume $\left(\mathbf{c m}^{3} / \mathbf{g}\right)$ & Average Pore Size $(\mathbf{n m})$ \\
\hline DG & 1.12 & $6.4 \times 10^{-5}$ & 29.47 \\
MDG & 3.54 & $12.1 \times 10^{-5}$ & 21.03 \\
\hline
\end{tabular}

\section{3. $p H$ Experiment and Zeta Potential Analysis}

The effect of $\mathrm{pH}$ of aqueous solution on adsorption of MG onto MDG is shown in Figure 9a. The adsorption capacity and adsorption removal rate increased as the $\mathrm{pH}$ rose from 1.0 to 6.0, and remained stable as the $\mathrm{pH}$ rose from 6.0 to 11.0. This is because MG is a cationic dye and, under acidic conditions, $\mathrm{MG}$ and $\mathrm{H}^{+}$have the same charge, both of them competing at active adsorption sites on MDG, resulting in a lower adsorption rate of 
MG. However, under alkaline conditions, MG has opposite charge due to $\mathrm{OH}-$, while MDG is negatively charged and adsorbs MG molecules through electrostatic interaction [44]. At a $\mathrm{pH}$ of 8 , the adsorption removal rate was maximum, i.e., $96.54 \%$, and when the $\mathrm{pH}$ was between 5 and 11, the adsorption removal rate was above $94.70 \%$. Therefore, the result shows that MDG can be applied to the treatment of dye wastewater with large $\mathrm{pH}$ fluctuations.

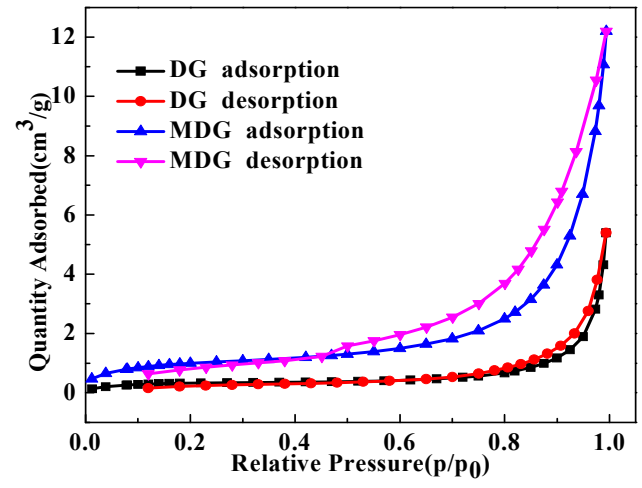

(a)

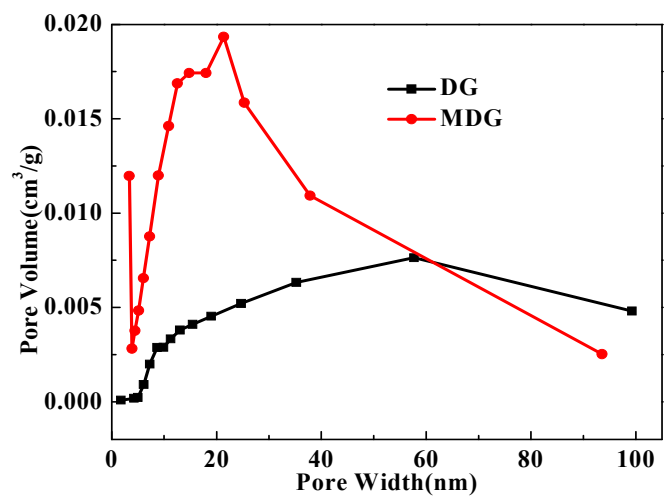

(b)

Figure 8. (a) $\mathrm{N}_{2}$ adsorption-desorption isotherm and (b) pore size distribution of DG and MDG.
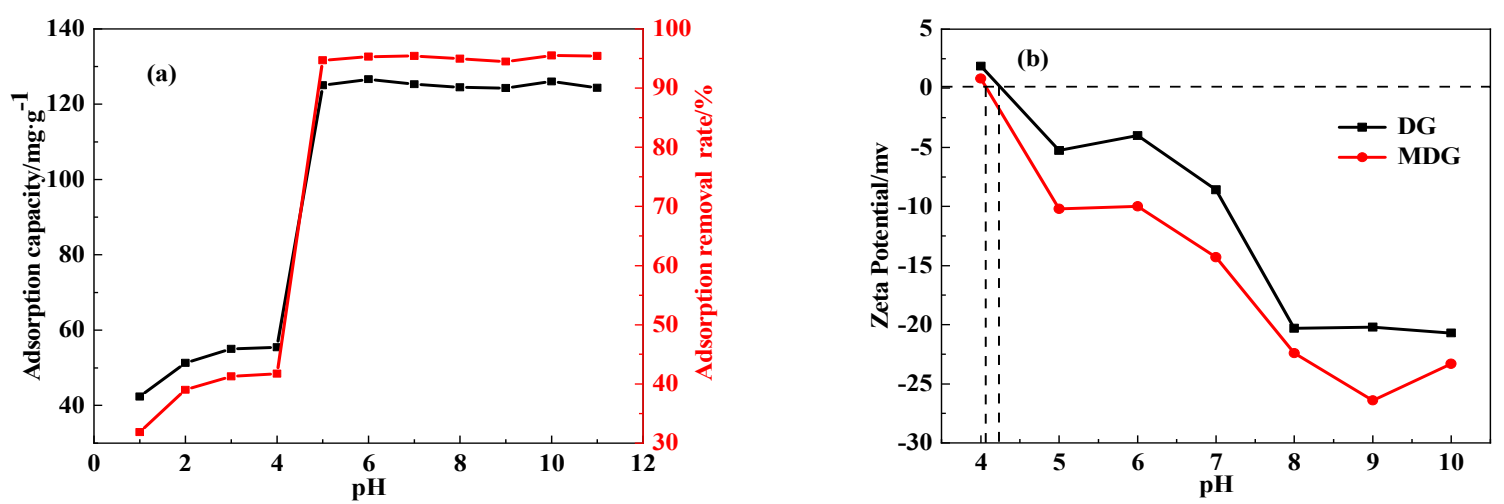

Figure 9. (a) Effect of $\mathrm{pH}$ on adsorption performance of MDG and (b) zeta potential analysis of DG and MDG.

Figure $9 \mathrm{~b}$ demonstrates the difference in zeta potential between DG and MDG at different $\mathrm{pH}$ values. It can be seen that the DG has positive zeta potential when the $\mathrm{pH}$ values are less than 4.2. This is due to the presence of a large number of -OH groups on DG before modification, which causes its surface to be electronegative. However, the point of zero potential value of MDG is lower than DG, which may be due to the modification of DG by $\mathrm{CS}_{2}$ to generate cellulose xanthate, which consumes part of -OH group on cellulose, resulting in a decrease in the total amount of -OH groups. MDG had access to a negatively charged ester group, leading to a negative shift in electrical properties. As the $\mathrm{pH}$ of the solution increases, the carboxyl group was gradually deprotonated, and the surface potential gradually decreased. MDG has good affinity for cationic dyes, so it can be proven that MDG might adsorb MG through electrostatic interaction.

\subsection{Adsorption Experiment}

Either DG or MDG $(0.195 \mathrm{~g})$ was added into $30 \mathrm{~mL}$ of MG solution at the rate of $200 \mathrm{mg} / \mathrm{L}$. The adsorption performance and adsorption parameters for both materials are shown in Figure 10 and Table 2, respectively. 


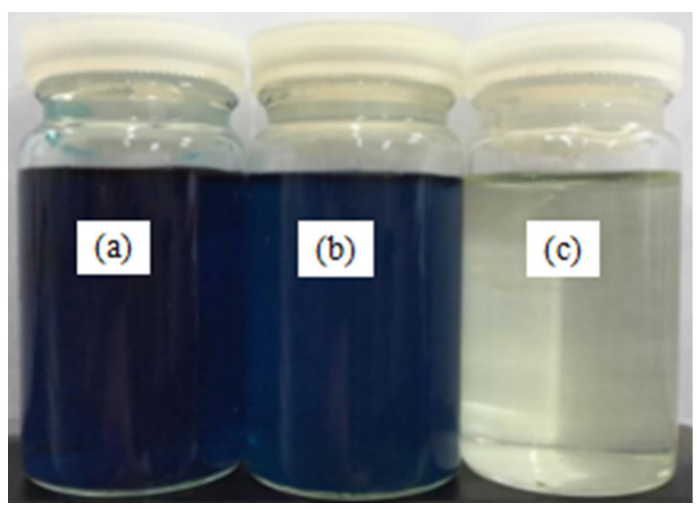

Figure 10. The photograph of (a) MG solution, (b) DG, and (c) MDG adsorption of MG solution.

Table 2. The adsorption performance parameters of DG and MDG on MG solution.

\begin{tabular}{ccc}
\hline Sample & $\eta(\%)$ & $\mathbf{q}_{\mathbf{e}}(\mathbf{m g} / \mathbf{g})$ \\
\hline DG & 50.04 & 7.67 \\
MDG & 96.38 & 14.78 \\
\hline
\end{tabular}

The adsorption of MG by DG lead to a light-colored solution, but the change in color was not obvious. The relative adsorption capacity and removal rate were $7.67 \mathrm{mg} / \mathrm{g}$ and $50.04 \%$, respectively. However, the adsorption of MG by MDG resulted in a nearly colorless solution, with a relative adsorption capacity and removal rate of $14.48 \mathrm{mg} / \mathrm{g}$ and 96.38\%, respectively. Compared with DG, MDG showed a $46.34 \%$ improvement in the removal rate and a $92.70 \%$ increase in the relative adsorption capacity, which further verified that DG has a much-enhanced adsorption capability after chemical modification (Figure 9, Table 2).

The influence of the amount of adsorbent on the adsorption performance of MDG is shown in Figure 11. It can be seen from Figure 11 that the adsorption rate increases first, and then becomes stable with the increase of the amount of adsorbent, while the adsorption amount decreases continuously, since the number of adsorption sites attached to MG molecules increases with the increase of MDG dosage; however, if the MG molecular concentration is certain, the number of adsorption sites it needs is certain. Further increasing the amount of MDG will cause the effective adsorption mass to be far less than the actual dosage.

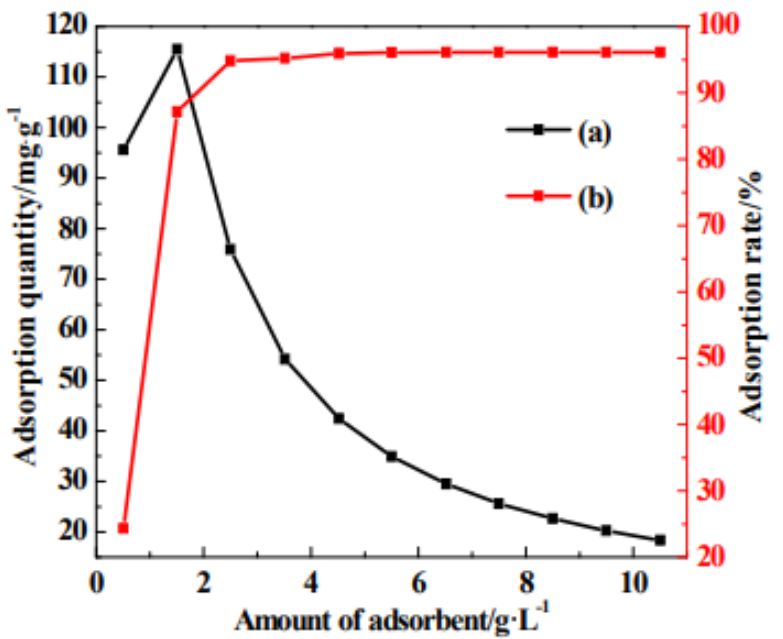

Figure 11. Effect of the amount of adsorbent on the adsorption performance of MDG. 


\subsection{MDG Regeneration Performance}

The regeneration of adsorbents is very important in industrial practices to ensure that wastewater treatment is economical [45]. The successful desorption with $\mathrm{HCl}$ solution is due to the reason that, under acidic conditions, $\mathrm{H}^{+}$in the solution competes with cationic dye molecules, causing the dye molecules to desorb from the adsorbent surface. The adsorption-desorption cycle of MDG was also evaluated. As shown in Figure 12, the adsorption removal rate of MDG remained almost unchanged in the first three cycles, and the adsorption removal rate after the third adsorption-desorption was $96.14 \%$. After eight adsorption-desorption cycle experiments, the adsorption removal rate of MDG to MG dye remained at $82.6 \%$. The result shows that MDG has good regeneration performance, and still has strong adsorption performance after multiple adsorption-desorption. This has the advantage of lowering cost of dye wastewater treatment. The repeated use of adsorbent saves energy and achieves green, clean production and environmental protection.

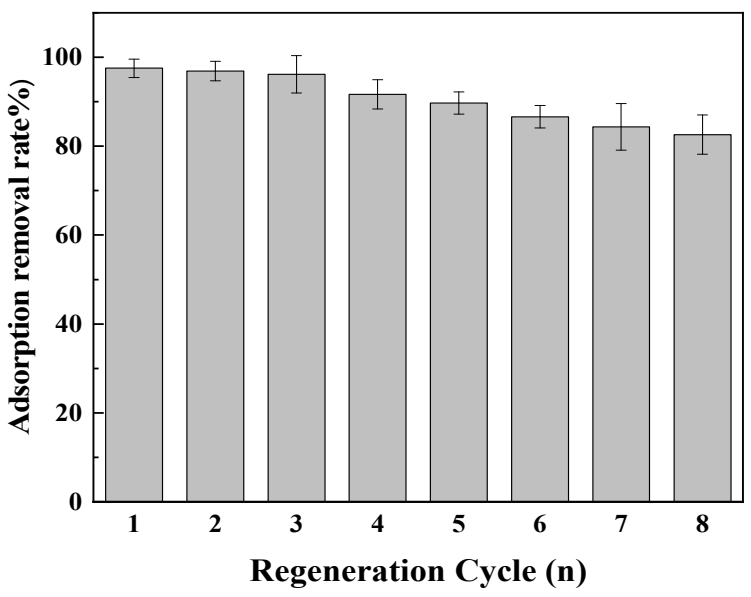

Figure 12. Regeneration properties of MDG.

\subsection{Adsorption Kinetics}

The adsorption experiments were performed at different temperature ranges, i.e., $298 \mathrm{~K}, 303 \mathrm{~K}$, and $308 \mathrm{~K}$ for 30, 60, 90, 120, 180, 240, and $300 \mathrm{~min}$, respectively, to discover the optimal adsorption time. The relationship between the adsorption time and adsorption performance of MDG for MG is shown in Figure 13.

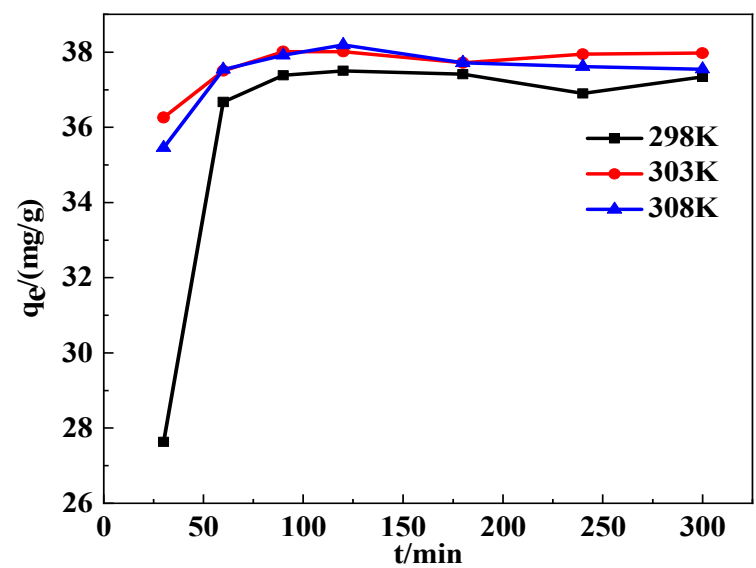

Figure 13. The effect of time on adsorption capacity at different temperatures.

At different temperatures, the adsorption capacity and adsorption removal rate of MG increased with the increase of adsorption time. The adsorption capacity gradually increased 
and stabilized after $240 \mathrm{~min}$, and finally reached the adsorption equilibrium, showing a maximum adsorption capacity of $38.19 \mathrm{mg} / \mathrm{g}$. At the beginning, concentration gradient between MG solution and the DG surface was large, and more sites were available for adsorption on MDG, therefore MG could easily combine with the MDG. With the increase in adsorption time, the pores of MDG were gradually filled with MG molecules. As a result, the surface adsorption sites were gradually saturated. Therefore, adsorption capacity and removal rate became slower and approached the equilibrium stage (Figure 13).

Further study on the adsorption mechanism of MDG for MG was explored using pseudo-first order and pseudo-second-order kinetic models (Figure 14 and Table 3) [46-49]. As presented in Table 3, the rate constant $\mathrm{k}_{2}$ increases with increasing temperature. Therefore, adsorption process of MDG for MG can be better explained with pseudo-second order model with correlation coefficient $R^{2}>0.998$. These results indicated that there was chemical interaction between adsorbent and adsorbate. The chemical bonding was the main factor affecting the pseudo-second-order kinetic model.
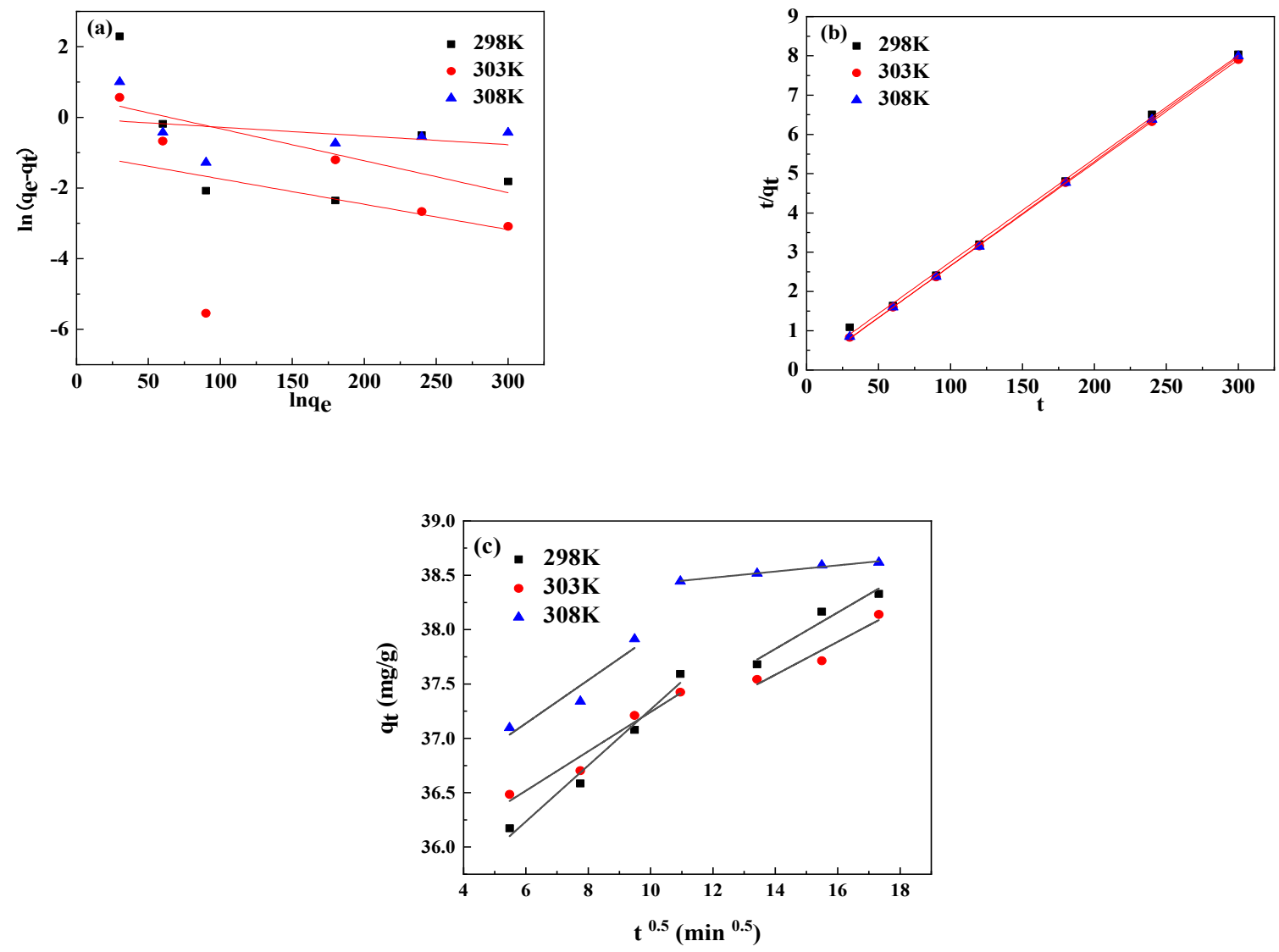

Figure 14. (a) Pseudo-first order and (b)pseudo-second order and (c) intra-particle diffusion kinetic models of MDG on adsorption of MG solution at different temperatures.

Table 3. Adsorption kinetic model parameters of Pseudo-first kinetic model pseudo-second kinetic model and intra-particle diffusion kinetic mode.

\begin{tabular}{ccccccccccc}
\hline \multirow{2}{*}{ Table. } & \multirow{2}{*}{$\mathbf{q}_{\mathbf{e}, \mathbf{e x p}}$} & \multicolumn{3}{c}{ First-Order Kinetic Model } & \multicolumn{3}{c}{ Second-Order Kinetic Model } & \multicolumn{3}{c}{ Intra-Particle Diffusion Kinetic Model } \\
\cline { 3 - 11 } & & $\mathbf{k}_{\mathbf{1}}$ & $\mathbf{q}_{\mathbf{e}, \mathbf{c a}}$ & $\mathbf{R}^{\mathbf{2}}$ & $\mathbf{k}_{\mathbf{2}}$ & $\mathbf{q}_{\mathbf{e}, \mathrm{cal}}$ & $\mathbf{R}^{\mathbf{2}}$ & $\mathbf{k}_{\mathbf{d}}$ & $\mathbf{q}_{\mathbf{e}, \mathbf{c a l}}$ & $\mathbf{R}^{\mathbf{2}}$ \\
\hline 298K & 37.50 & 0.009 & 1.79 & 0.141 & 0.006 & 38.01 & 0.998 & 0.195 & 34.69 & 0.967 \\
$303 \mathrm{~K}$ & 38.01 & 0.007 & 0.36 & -0.090 & 0.029 & 38.08 & 0.999 & 0.181 & 35.43 & 0.935 \\
$308 \mathrm{~K}$ & 38.19 & 0.003 & 0.97 & -0.097 & 0.287 & 37.66 & 0.999 & 0.028 & 38.14 & 0.969 \\
\hline
\end{tabular}


The intra-particle diffusion kinetics of MG onto MDG at different temperatures are shown in Figure 14c. If the plot of qt versus t0.5 gives a straight line that passes through the origin of coordinates, then the adsorption process is controlled by intraparticle diffusion only. However, the data present a multi-non-linear graph, with straight lines deviating from the origin. The first straight line describes the intraparticle diffusion of dye molecules in the macropores of MDG, the second straight line represents the diffusion in the micropores. The results show that intra-particle diffusion is not the controlling mechanism in the adsorption system [50-52]. The result reveals that intraparticle diffusion is not the controlling mechanism in the adsorption system.

\subsection{Isothermal Model of Adsorption}

The effect of different MG concentrations (100, 200, 300, 400, 500, 600, and $700 \mathrm{mg} / \mathrm{L})$ on adsorption performance were determined using the adsorption experiments of MDG for MG solutions at 298 K, 303 K, and 308 K, and the results are shown in Figure 15. At different temperatures, increase in MG concentration significantly increased the adsorption capacity. This is because higher MG concentration increases the collision frequency between MG molecules and the adsorbent. At fixed adsorbent amount, the number of active sites remained constant. Therefore, increased MG solution concentration resulted in saturation of active sites, which resulted in gradual decrease in the removal rate.

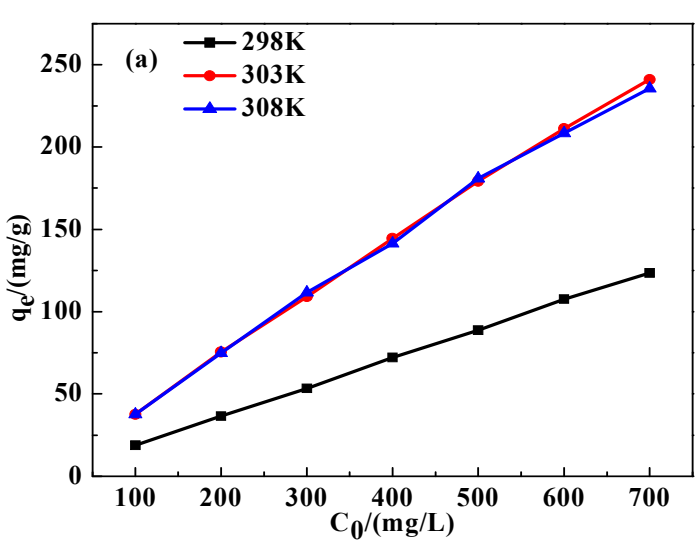

(a) $\mathrm{C}_{0} \sim \mathrm{qe}$

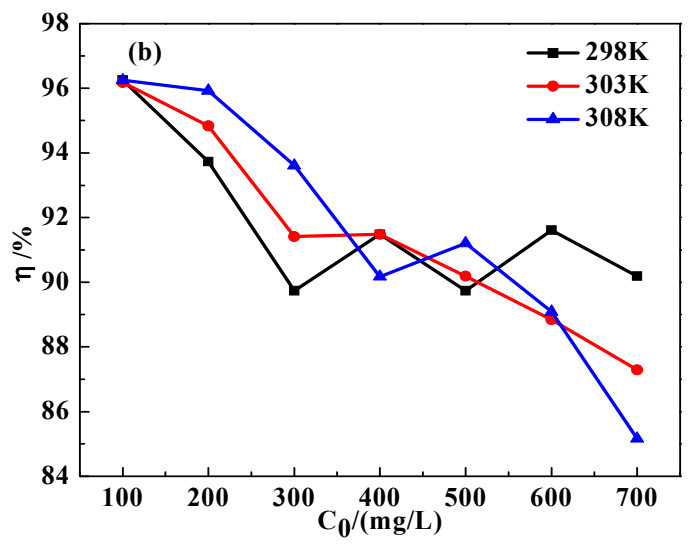

(b) $\mathrm{C}_{0} \sim \eta$

Figure 15. The effect of initial concentration of MG on (a) adsorption capacity and (b) adsorption removal rate at different temperatures.

The experimental data was better supported with the Langmuir, Freundlich, and Temkin isotherms (Figure 16). The parameters of isotherms are shown in Table 4. The non-linear Freundlich isotherm fits the adsorption process well, with $\mathrm{R}^{2}>0.938$ (Table 4). As the temperature increased, KF value also rises, showing higher adsorption capacity of the MDG, and there was better affinity between MDG and MG. In addition, the fitted heterogeneity factors of Freundlich isotherm $(1 / n)$ were all between 0 and 1 , indicating that the adsorption process is favorable. These results indicate that the MDG has a non-uniform surface, the adsorption capacity of MDG increased with the increase in concentration of MG, and there was an interaction between MG molecules, which is consistent with the results shown in Figure 15a. The non-linearity of the Langmuir model is higher with $\mathrm{R}^{2}>0.972$ (Table 4), indicating that the surface of adsorbent has a relatively homogeneous and regular pore structure [53]. 

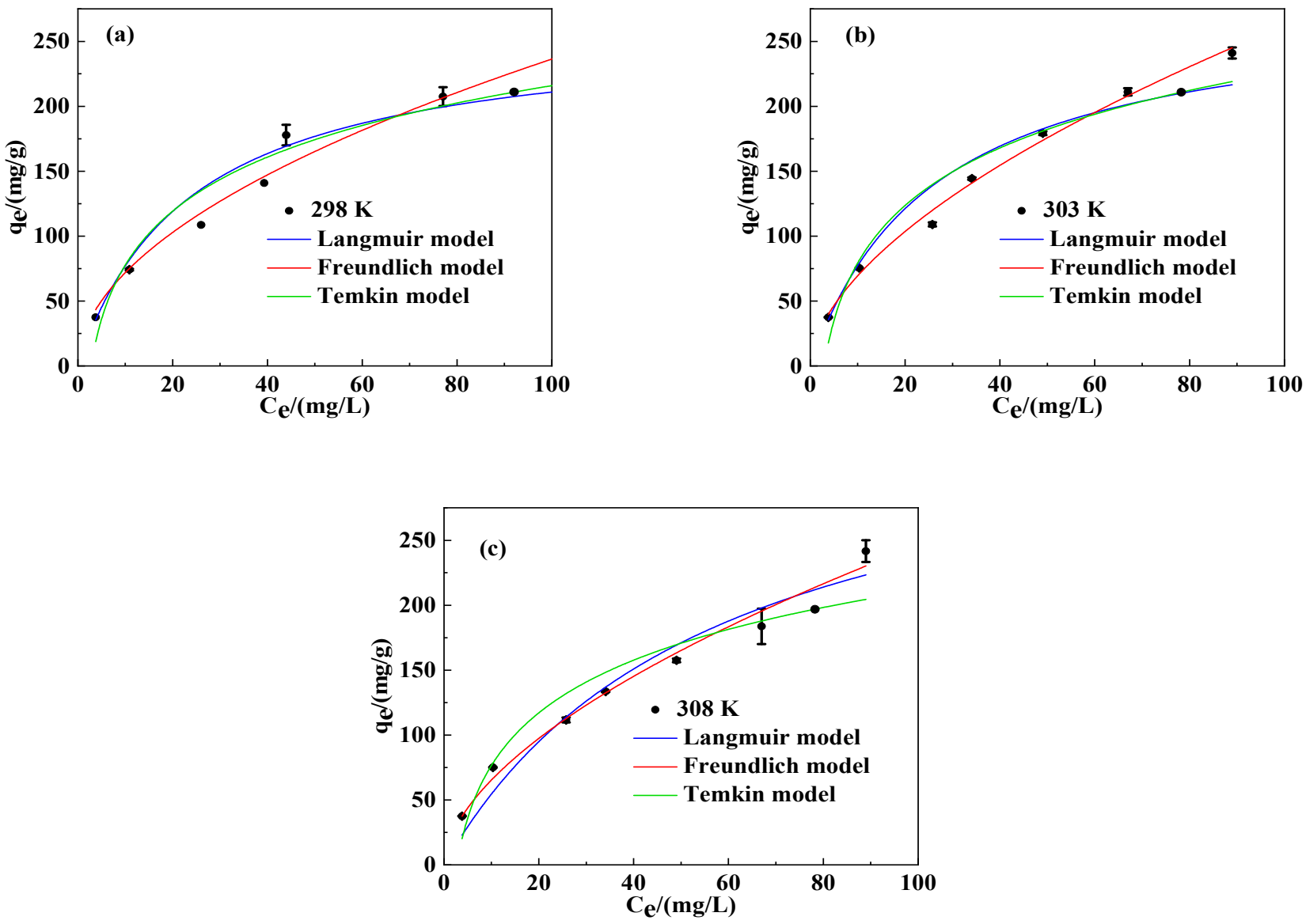

Figure 16. Langmuir, Freundlich, and Temkin isotherm model of MDG on adsorption of MG solution at (a) $298 \mathrm{~K},(\mathbf{b}) 303 \mathrm{~K}$ and (c) $308 \mathrm{~K}$.

Table 4. Langmuir, Freundlich, and Temkin adsorption isotherm model parameters.

\begin{tabular}{cccccccccc}
\hline \multirow{2}{*}{$\mathbf{T}(\mathbf{K})$} & \multicolumn{3}{c}{ Langmuir Equation } & \multicolumn{3}{c}{ Freundlich Equation } & \multicolumn{3}{c}{ Temkin Equation } \\
\cline { 2 - 10 } & $\mathbf{q}_{\mathbf{m}} \mathbf{( \mathbf { m g } / \mathbf { g } )}$ & $\mathbf{K}_{\mathbf{L}}(\mathbf{m} \mathbf{L} / \mathbf{g})$ & $\mathbf{R}^{\mathbf{2}}$ & $\mathbf{K}_{\mathbf{F}}(\mathbf{m g} / \mathbf{g})$ & $\mathbf{1 / \mathbf { n } _ { \mathbf { F } }}$ & $\mathbf{R}^{\mathbf{2}}$ & $\boldsymbol{\alpha}_{\mathbf{T}}(\mathbf{L} / \mathbf{m g})$ & $\boldsymbol{\beta}_{\mathbf{T}}(\mathbf{J} / \mathbf{m o l})$ & $\mathbf{R}^{\mathbf{2}}$ \\
\hline 298 & 261.48 & 0.042 & 0.938 & 21.87 & 0.52 & 0.972 & 0.36 & 41.24 & 0.925 \\
303 & 280.68 & 0.038 & 0.944 & 18.41 & 0.58 & 0.992 & 0.35 & 39.41 & 0.921 \\
308 & 367.39 & 0.017 & 0.945 & 17.35 & 0.58 & 0.984 & 0.37 & 43.74 & 0.893 \\
\hline
\end{tabular}

\subsection{Adsorption Thermodynamics}

The temperature effect on the adsorption process for MG solution with different concentrations was studied (Figure 17). Results of the experiment showed an increase in adsorption capacity with increasing temperature. Figure 17 and Table 5 show the thermodynamics analysis and the relevant parameters of the adsorption process of MDG for MG. The $\Delta \mathrm{G} 0$ values of MDG for MG at $298 \mathrm{~K}, 303 \mathrm{~K}$, and $308 \mathrm{~K}$ were all negative. It is shown that the adsorption is a spontaneous process. In addition, the $\Delta \mathrm{G} 0$ gradually decreased with an increase in temperature, which means a better adsorption of MG can be obtained at high temperature, i.e., the reaction is easier to proceed. The value of $\Delta \mathrm{H}_{0}$ is positive which indicates that adsorption was an endothermic process and was more likely to occur at high temperature, and was consistent with the temperature effect on the adsorption (Table 4 ). The positive value of $\Delta S_{0}$ points toward the uncertainty between adsorbent and adsorbate at the interface, which increased during the adsorption process and indicates that adsorption process was more likely to occur [54]. 


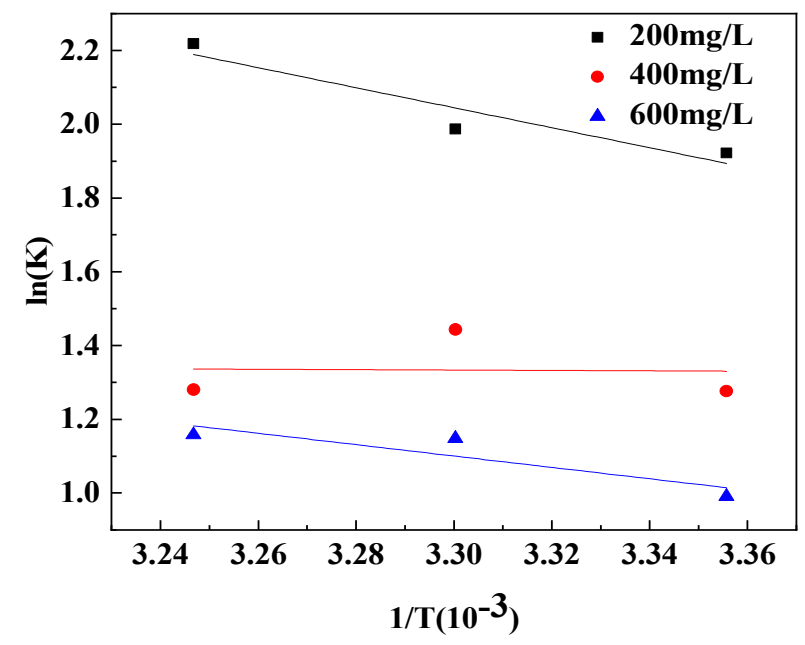

Figure 17. Thermodynamic analysis of MDG on adsorption of MG solution at different temperatures.

Table 5. Adsorption thermodynamic parameters.

\begin{tabular}{|c|c|c|c|c|c|}
\hline \multirow{2}{*}{$\mathrm{C}_{0} /\left(\mathrm{mg} \cdot \mathrm{L}^{-1}\right)$} & \multirow{2}{*}{$\Delta \mathrm{H}_{0} /\left(\mathrm{kJ} \cdot \mathrm{mol}^{-1}\right)$} & \multirow{2}{*}{$\Delta \mathrm{S}_{0} /(\mathrm{J} \cdot \mathrm{mol} \cdot \mathrm{K})$} & \multicolumn{3}{|c|}{$\Delta \mathrm{G}_{0} /\left(\mathrm{kJ} \cdot \mathrm{mol}^{-1}\right)$} \\
\hline & & & $298 \mathrm{~K}$ & $303 \mathrm{~K}$ & $308 \mathrm{~K}$ \\
\hline 200 & 22.54 & 91.39 & -4.76 & -5.01 & -5.68 \\
\hline 400 & 0.45 & 12.56 & -3.16 & -3.64 & -3.28 \\
\hline 600 & 12.82 & 51.46 & -2.46 & -3.28 & -2.97 \\
\hline
\end{tabular}

\subsection{Adsorption Molecular Simulation}

In the simulation, the system was annealed from $1 \times 10^{5} \mathrm{~K}$ to $100 \mathrm{~K}$. Using the smart method, the force field used was UFF force field. When the energy convergence reached $1 \times 10^{-4} \mathrm{kcal} / \mathrm{mol}$, the simulation was considered to be over.

Figure 18 shows the adsorption heat of seven kinds of stochastic simulated adsorption configurations of DG and MDG fibers ( -110$)$ surface-adsorbed on MG molecules, and Figure 19 shows the simulated adsorption of MG molecules on the surface of DG fibers $(-110)$ surface adsorption model of configuration B. Figure 20 is an adsorption model of the simulated adsorption configuration c of the MDG (-1 10$)$ surface-adsorbed MG molecule. MG molecule is labeled as the green molecule. The adsorption energy is the total energy of the system, i.e., after adsorption minus the energy before adsorption. The more negative the adsorption energy, the easier it is to adsorb MG.

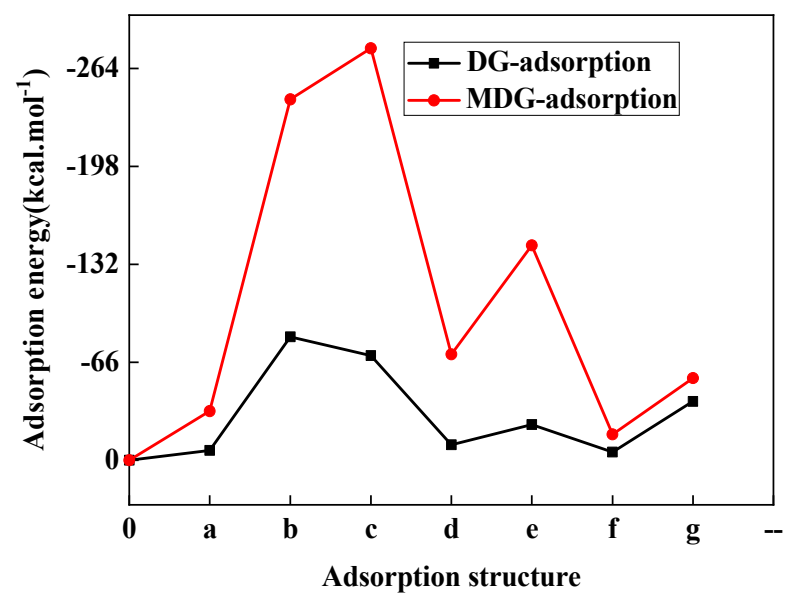

Figure 18. Adsorption energy of different adsorption configurations of MG molecules adsorbed by DG/MDG fiber ( -110$)$ surface. 


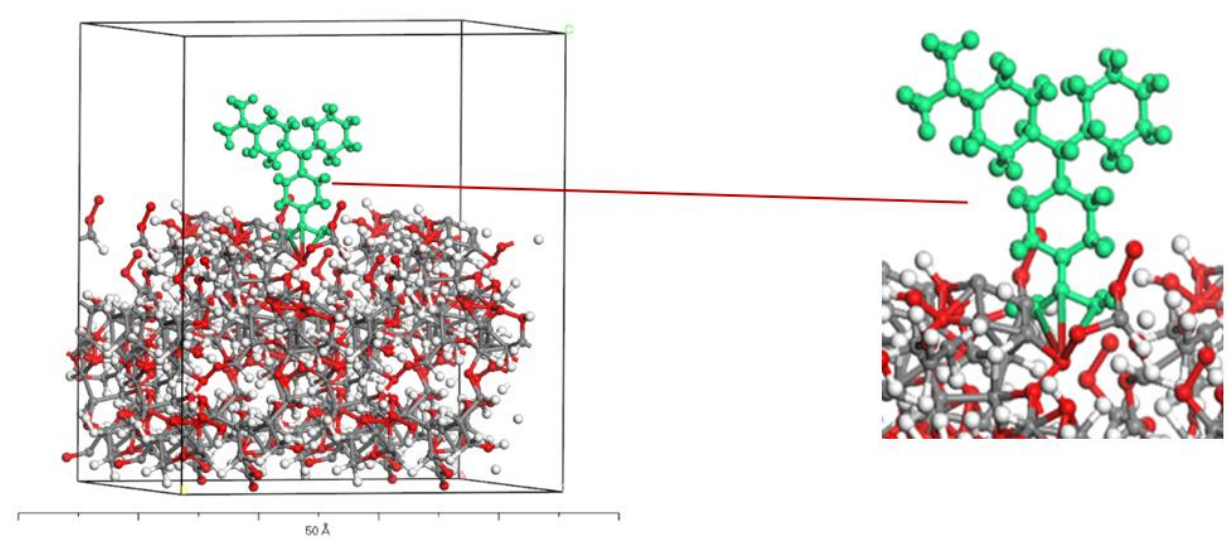

Figure 19. DG fiber ( -110$)$ surface and single MG molecular simulation (structure B) adsorption configuration.

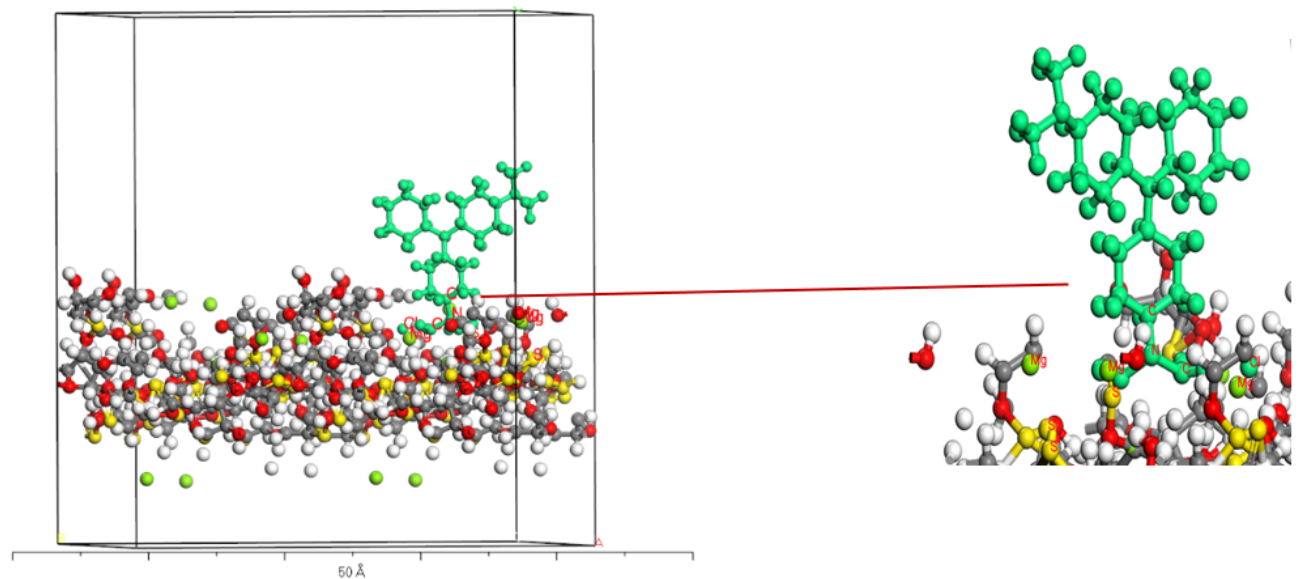

Figure 20. MDG fiber ( -110$)$ surface and single MG molecular adsorption simulation (structure C) configuration.

Adsorption heat of the MDG ( $\left.\begin{array}{lll}-1 & 1 & 0\end{array}\right)$ surface was higher than the DG (-1 10 ) surface, which indicates that MDG more likely to adsorbs MG than DG, and the adsorption heat was uniformly arranged (Figure 18). The adsorption energy of DG fiber, adsorption configuration B and MDG fiber adsorption configuration C reached $-83.13 \mathrm{kcal} / \mathrm{mol}$ and $-277.57 \mathrm{kcal} / \mathrm{mol}$, respectively. The DG heat increased by 3.34 times after MDG. Adsorption configuration B of the MG molecule on the DG is an upright adsorption configuration, and the MG molecule tends to adsorb directly above the surface of the DG cellulose, referred to as the top position on the surface of the DG molecule-OH (Figure 19). Oxygen-containing functional groups showed no obvious change in the position. The structure of DG fibers is tight, and the groups can easily form hydrogen bonds between molecules. It can be seen that DG and MG are physically adsorbed, exhibiting weak chemical adsorption.

The adsorption configuration of the MG molecule on the DG is also an upright adsorption configuration, and the MG molecule tends to adsorb to the midpoint of most adjacent monomer on the surface of MDG fiber (the bridge position), which is mainly assisted by the MG molecule (Figure 20). The auxiliary group is $-\mathrm{N}\left(\mathrm{CH}_{2} \mathrm{CH}_{3}\right)_{2}$. In Figure 20, $\mathrm{Cl}^{-}$of $\mathrm{MG}$ is close towards the $\mathrm{Mg}^{+}$direction of MDG, thus $-\mathrm{N}^{+}\left(\mathrm{CH}_{2} \mathrm{CH}_{3}\right)_{2}$ is more stably attached to the surface of the anionic MDG [55], and each chemical addition of $\mathrm{C}=\mathrm{S}$ in the MDG fiber molecule has strong chemical adsorption, therefore the MG molecule has stronger affinity for MDG. 
Generally, the absolute value of the adsorption energy was greater than $40 \mathrm{kcal} / \mathrm{mol}$ for chemical adsorption, but remained less than $40 \mathrm{kcal} / \mathrm{mol}$ for physical adsorption. The highest and lowest adsorption heats of the DG (-1 10$)$ surface adsorption MG molecule $\mathrm{a} \sim \mathrm{g}$ configuration were $-83.13 \mathrm{kcal} / \mathrm{mol}$ and $-5.49 \mathrm{kcal} / \mathrm{mol}$, respectively, indicating the presence of chemisorption. However, the physical adsorption was dominant; the highest and lowest adsorption heat of the MDG (-1 10 ) surface adsorption MG molecule a g configuration was $-277.57 \mathrm{kcal} / \mathrm{mol}$ and $-17.46 \mathrm{kcal} / \mathrm{mol}$, respectively. It showed that chemical adsorption was main phenomena, but some physical adsorption was also noted. The simulation results were consistent with the results obtained by previous experiments. Results were in accordance with the adsorption pseudo-second order. The adsorption on the substrate was more stable when adsorption energy was more negative, i.e., MDG was more likely to adsorb MG molecules than DG, and the adsorption to MDG was very stable This was due to the strong hydrogen bonding between DG molecules, therefore it was difficult to generate chemical bonds in molecules. The smaller the adsorption energy, the greater the desorption energy, which means that the desorption ability was stronger. The simulation also indirectly showed that the MDG fiber molecules have strong adsorption-desorption potential, which provides a realistic basis for the future adsorption and utilization of distiller's grains.

\subsection{Adsorption Simulation Interaction Energy}

The adsorption model of DG and MDG molecules and MG molecules in a water molecular system was established in the amorphous cell module according to the previous experimental ratio. The density distribution of MG molecules in solution system was simulated at $298 \mathrm{~K}$. The system was annealed from $1 \times 10^{5} \mathrm{~K}$ to $100 \mathrm{~K}$. When the energy convergence reached $1 \times 10^{-4} \mathrm{kcal} / \mathrm{mol}$, the simulation was considered to be completed.

Table 6 shows the adsorption density distribution of MG molecules adsorbed by DG and MDG in aqueous solution, the number of MG molecules adsorbed by single cell, the van der Waal energy, the electrostatic energy, and the binding energy in the system. The yellow density is the adsorbed MG in the adsorption density distribution map. It can be seen that in the amorphous aqueous solution, the number of molecules adsorbing MG by DG and MDG is two and six, respectively, and the number of molecules adsorbed by single cell is the amount of adsorption, i.e., the amount of MDG adsorption is greater than DG adsorption (Table 6).

Table 6. DG and MDG AC simulated adsorption interaction.

\begin{tabular}{|c|c|c|}
\hline & DG Adsorption Model & MDG Adsorption Model \\
\hline Adsorption density configuration & 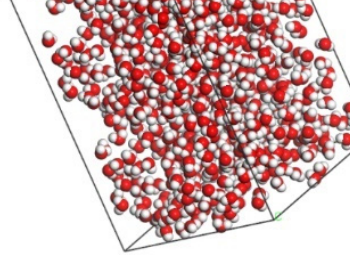 & 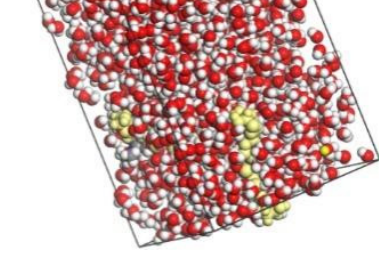 \\
\hline $\begin{array}{c}\text { Single cell adsorption molecule numbers } \\
\text { Van der Waal }(\mathrm{kcal} / \mathrm{mol}) \\
\text { Static energy }(\mathrm{kcal} / \mathrm{mol}) \\
\text { Binding energy }(\mathrm{kcal} / \mathrm{mol})\end{array}$ & $\begin{array}{c}2 \\
-82.482 \\
-156.236 \\
238.718\end{array}$ & $\begin{array}{c}6 \\
-421.565 \\
-120.514 \\
542.079\end{array}$ \\
\hline
\end{tabular}


The binding energy of crystal is the difference between the total energy of an atom in a crystal when it is in a free state minus the total energy of the entire system when the crystal is stable [56]. The interfacial bonding energy is mainly due to the interaction between the interfaces. This effect is mainly the sum of van der Waals force and electrostatic action.

The binding energy of DG and MDG adsorption model after simulated annealing was $238.718 \mathrm{kcal} / \mathrm{mol}$ and $542.079 \mathrm{kcal} / \mathrm{mol}$, respectively, and the binding energy of the MDG system was greater than the DG system (Table 6). The greater the binding energy, the more stable the system, i.e., the MDG adsorption by MG system in aqueous solution was more stable. The binding energy is related to the type of bond formation. DG was esterified with $\mathrm{CS}_{2}$ to form xanthate cellulose, which forms chemical bonds such as $\mathrm{C}-\mathrm{O}, \mathrm{C}-\mathrm{S}, \mathrm{O}-\mathrm{C}=\mathrm{S}, \mathrm{C}=\mathrm{S}$. Therefore, the MDG system can be combined with DG.

\subsection{Comparison of Adsorption Capacity of Various Adsorbents to Remove MG}

Table 7 shows the comparison of various adsorbents and MDG maximum adsorption capacity for MG dyes reported in recent years. It can be seen from Table 7 that the maximum monolayer adsorption capacity of MG on MDG in this study was $367.39 \mathrm{mg} / \mathrm{g}$, which is a higher adsorption capacity than other adsorption capacities. The results of this study indicate that MDG is a promising candidate adsorbent for the removal of MG from aqueous solutions, providing a new direction for the current treatment of printing and dyeing wastewater, and recycling of abandoned distiller's grains.

Table 7. Comparison of the developed MDG with the other reported materials for removal of MG.

\begin{tabular}{|c|c|c|c|c|}
\hline Adsorbent & Dye & Adsorption Efficiency & $q_{\max }(\mathrm{mg} / \mathrm{g})$ & Reference \\
\hline Poly (methyl methacrylate)/graphene oxide-Fe3O & MG & $92 \%$ & $3-3.5$ & [57] \\
\hline $\begin{array}{l}\text { GO/cellulose bead composite } \\
\text { (5 wt\%-GOCB) composite }\end{array}$ & MG & $>96 \%$ & 17.86 & [58] \\
\hline PANI-HCl/TMP nanocomposite & MG & $75-100 \%$ & 78.9 & [59] \\
\hline Magnetic Activated Carbon & MG & $96 \%$ & 106.5 & [60] \\
\hline $\mathrm{NaOH}$ modified Luffa aegyptiaca peel & MG & $90 \%$ & 161 & {$[61]$} \\
\hline Ultra-light weight aerogels & MG & $92 \%$ & 212.7 & [62] \\
\hline Three D MBCNF/GOPA & MG & $93 \%$ & 270.27 & [63] \\
\hline$\beta-\mathrm{MCM}-41$ silica/RH composite & MG & $29.68-97.11 \%$ & 285 & [64] \\
\hline Modified distiller's grains(MDG) & MG & $96.51 \%$ & 367.39 & This study \\
\hline
\end{tabular}

\section{Conclusions}

In the present work, a novel MDG was successfully prepared from $\mathrm{CS}_{2}$-modified waste distillers' grains. FTIR and XRD results evidenced that the groups in MDG have changed, but that modification treatment did not change the structure of cellulose. The adsorption results indicated that increase in adsorption time results in a gradual increase of adsorption capacity and removal rate until the equilibrium stage was attained after $240 \mathrm{~min}$. The increase in initial concentration of MG in the wastewater resulted in an increase in adsorption capacity and a decrease in removal rate. The maximum removal rate was $96.51 \%$, and after eight adsorption-desorption cycle experiments, the adsorption removal rate of MDG to MG dye remained at $82.6 \%$. The kinetic studies indicated that adsorption mechanism of MDG, DG for MG was in accordance with the pseudo-second order kinetic model $\left(\mathrm{R}^{2}>0.998\right)$ and $\mathrm{k}_{2}$ increased with rise in temperature. The Freundlich adsorption isotherm equation perfectly described the adsorption process of MDG, DG, and MG $\left(\mathrm{R}^{2}>0.967\right)$. MDG has better adsorption capacity, up to $367.39 \mathrm{mg} / \mathrm{g}$, and its maximum adsorption capacity for MG adsorption is greater than reported in other literatures. The thermodynamic analysis indicated that adsorption mechanism was a spontaneous $\left(\Delta \mathrm{G}_{0}<0\right)$, endothermic $\left(\Delta \mathrm{H}_{0}>0\right)$, and entropy increasing process $\left(\Delta \mathrm{S}_{0}>0\right)$. Through the molecular simulation adsorption process, it was confirmed that MDG adsorption of MG was mainly chemical adsorption. MDG was more likely to adsorb MG molecules than DG, and was most stable on the distiller's fiber. The MDG is a promising candidate adsorbent 
for the removal of MG from aqueous solutions. It not only provides a high-efficiency and low-cost dye wastewater treatment option, but also provides a new direction for the recovery and reuse of waste distiller's grains, which ultimately helps in achieving energy conservation, emission reduction, and environmental protection.

Author Contributions: Conceptualization, C.L. and C.W.; methodology, D.K. and X.M.; software, X.M.; resources, H.W.; writing-original draft preparation, D.K. and X.M.; writing-review and editing, D.K.; funding acquisition, X.Y., C.W. and H.W. All authors have read and agreed to the published version of the manuscript.

Funding: This research was funded by the Open Research Fund Program of Key Laboratory of Cleaner Production and Integrated Resource Utilization of China National Light Industry (CP-2018YB2), Liquor making Biological Technology and Application of key laboratory of Sichuan Province (NJ2019-01), Key Laboratory of Wuliangye-flavor Liquor Solid-state Fermentation, China National Light Industry (2018JJ005).

Conflicts of Interest: The authors declare no conflict of interest.

\section{References}

1. Wang, X.J.; Ullah, N.; Sun, X.C.; Guo, X.; Chen, L.; Li, Z.X.; Feng, X.C. Development and characterization of bacterial cellulose reinforced biocomposite films based on protein from buckwheat distiller's dried grains. Int. J. Biol. Macromol. 2016, 96, 353-360. [CrossRef] [PubMed]

2. Zuo, S.C.; Yang, H.Q.; Zou, W. Recent Progress on the Utilization of Distiller's Grains: A Review. Food Ind. 2016, 37, $246-249$.

3. Rahmani, M.; Kaykhaii, M.; Sasani, M. Application of Taguchi L16 design method for comparative study of ability of 3A zeolite in removal of Rhodamine B and Malachite green from environmental water samples. Spectrochim. Acta Part A Mol. Biomol. Spectrosc. 2018, 188, 164-169. [CrossRef] [PubMed]

4. Pei, C.; Han, G.; Zhao, Y.; Zhao, H.; Liu, B.; Cheng, L.; Yang, H.; Liu, S. Superior adsorption performance for triphenylmethane dyes on 3D architectures assembled by ZnO nanosheets as thin as $~ 1.5 \mathrm{~nm}$. J. Hazard. Mater. 2016, 318, 732-741. [CrossRef]

5. Guadie, A.; Tizazu, S.; Melese, M.; Guo, W.; Ngo, H.H.; Xia, S. Biodecolorization of textile azo dye using Bacillus sp. strain CH12 isolated from alkaline lake. Biotechnol. Rep. 2017, 15, 92-100. [CrossRef] [PubMed]

6. Dil, E.A.; Ghaedi, M.; Asfaram, A.; Mehrabi, F.; Bazrafshan, A.A. Optimization of process parameters for determination of trace Hazardous dyes from industrial wastewaters based on nanostructures materials under ultrasound energy. Ultrason. Sonochemistry 2018, 40, 238-248. [CrossRef]

7. Goda, E.S.; Singu, B.S.; Hong, S.E.; Yoon, K.R. Good dispersion of poly( $\delta$-gluconolactone)-grafted graphene in poly(vinyl alcohol) for significantly enhanced mechanical strength. Mater. Chem. Phys. 2020, 254, 123465. [CrossRef]

8. Kadioglu, O.; Keskin, S. Efficient separation of helium from methane using MOF membranes. Sep. Purif. Technol. 2018, 191, 192-199. [CrossRef]

9. Saffari, M.; Ebrahimi, A.; Langrish, T. Nano-confinement of acetaminophen into porous mannitol through adsorption method. Microporous Mesoporous Mater. 2016, 227, 95-103. [CrossRef]

10. Zhou, Y.; Zhang, R.; Chen, K.; Zhao, X.; Gu, X.; Lu, J. Enhanced adsorption and photo-degradation of bisphenol A by $\beta$-cyclodextrin modified pine sawdust in an aquatic environment. J. Taiwan Inst. Chem. Eng. 2017, 78, 510-516. [CrossRef]

11. Shehzad, K.; Xie, C.; He, J.; Cai, X.; Xu, W.; Liu, J. Facile synthesis of novel calcined magnetic orange peel composites for efficient removal of arsenite through simultaneous oxidation and adsorption. J. Colloid Interface Sci. 2018, 511, 155-164. [CrossRef]

12. Wang, W.; Deng, S.; Li, D.; Ren, L.; Shan, D.; Wang, B.; Huang, J.; Wang, Y.; Yu, G. Sorption behavior and mechanism of organophosphate flame retardants on activated carbons. Chem. Eng. J. 2018, 332, 286-292. [CrossRef]

13. Liu, J.; Wang, Z.; Li, H.; Hu, C.; Raymer, P.; Huang, Q. Effect of solid state fermentation of peanut shell on its dye adsorption performance. Bioresour. Technol. 2018, 249, 307-314. [CrossRef]

14. Fito, J.; Tefera, N.; Van Hulle, S.W. Adsorption of distillery spent wash on activated bagasse fly ash: Kinetics and thermodynamics. J. Environ. Chem. Eng. 2017, 5, 5381-5388. [CrossRef]

15. Noor, N.M.; Othman, R.; Mubarak, N.; Abdullah, E.C. Agricultural biomass-derived magnetic adsorbents: Preparation and application for heavy metals removal. J. Taiwan Inst. Chem. Eng. 2017, 78, 168-177. [CrossRef]

16. Sayğılı, H.; Güzel, F. High surface area mesoporous activated carbon from tomato processing solid waste by zinc chloride activation: Process optimization, characterization and dyes adsorption. J. Clean. Prod. 2016, 113, 995-1004. [CrossRef]

17. Yakout, S.M.; Hassan, M.R.; Abdeltawab, A.A.; Aly, M.I. Sono-sorption efficiencies and equilibrium removal of triphenylmethane (crystal violet) dye from aqueous solution by activated charcoal. J. Clean. Prod. 2019, 234, 124-131. [CrossRef]

18. Bhowmik, M.; Deb, K.; Debnath, A.; Saha, B. Mixed phase $\mathrm{Fe}_{2} \mathrm{O}_{3} / \mathrm{Mn}_{3} \mathrm{O}_{4}$ magnetic nanocomposite for enhanced adsorption of methyl orange dye: Neural network modeling and response surface methodology optimization. Appl. Organomet. Chem. 2017, 32, e4186. [CrossRef]

19. Bhowmik, M.; Debnath, A.; Saha, B. Fabrication of mixed phase calcium ferrite and zirconia nanocomposite for abatement of methyl orange dye from aqua matrix: Optimization of process parameters. Appl. Organomet. Chem. 2018, 32, e4607. [CrossRef] 
20. Bhowmik, M.; Debnath, A.; Saha, B. Fabrication of mixed phase $\mathrm{CaFe}_{2} \mathrm{O}_{4}$ and $\mathrm{MnFe}_{2} \mathrm{O}_{4}$ magnetic nanocomposite for enhanced and rapid adsorption of methyl orange dye: Statistical modeling by neural network and response surface methodology. J. Dispers. Sci. Technol. 2019, 41, 1937-1948. [CrossRef]

21. Abu Elella, M.H.; Elhafeez, E.A.; Goda, E.S.; Lee, S.; Yoon, K.R. Smart bactericidal filter containing biodegradable polymers for crystal violet dye adsorption. Cellulose 2019, 26, 9179-9206. [CrossRef]

22. Li, C.; Wu, N.; Zhang, M.; Wei, C.; Yan, F.; Wang, Z. Effects of E44 and KH560 modifiers on properties of distillers grains poly(butylene succinate) composites. Polym. Compos. 2018, 40, 1499-1509. [CrossRef]

23. Wang, B.; Lian, G.; Lee, X.; Gao, B.; Li, L.; Liu, T.; Zhang, X.; Zheng, Y. Phosphogypsum as a novel modifier for distillers grains biochar removal of phosphate from water. Chemosphere 2019, 238, 124684. [CrossRef]

24. Xu, Q.; Liu, T.; Li, L.; Liu, B.; Wang, X.; Zhang, S.; Li, L.; Wang, B.; Zimmerman, A.R.; Gao, B. Hydrothermal carbonization of distillers grains with clay minerals for enhanced adsorption of phosphate and methylene blue. Bioresour. Technol. 2021, 340,125725 [CrossRef]

25. Wang, H.; Xie, R.; Zhang, J.; Zhao, J. Preparation and characterization of distillers' grain based activated carbon as low cost methylene blue adsorbent: Mass transfer and equilibrium modeling. Adv. Powder Technol. 2017, 29, 27-35. [CrossRef]

26. Oliveira, K.R.; Segura, J.G.; Oliveira, B.A.; Medeiros, A.; Zimba, R.D.; Viegas, E.M. Distillers' dried grains with soluble in diets for Pacu, Piaractus mesopotamicus juveniles: Growth performance, feed utilization, economic viability, and phosphorus release. Anim. Feed. Sci. Technol. 2020, 262, 114393. [CrossRef]

27. Lee, C.; Morris, D.; Lefever, K.; Dieter, P. Feeding a diet with corn distillers grain with solubles to dairy cows alters manure characteristics and ammonia and hydrogen sulfide emissions from manure. J. Dairy Sci. 2020, 103, 2363-2372. [CrossRef]

28. Zhang, Z.; Wang, Q.; Li, L.; Xu, G. Pyrolysis characteristics, kinetics and evolved volatiles determination of rice-husk-based distiller's grains. Biomass-Bioenergy 2020, 135, 105525. [CrossRef]

29. Tan, L.; Zhu, D.; Zhou, W.; Mi, W.; Ma, L.; He, W. Preferring cellulose of Eichhornia crassipes to prepare xanthogenate to other plant materials and its adsorption properties on copper. Bioresour. Technol. 2008, 99, 4460-4466. [CrossRef]

30. Huang, Z.; Li, Y.; Chen, W.; Shi, J.; Zhang, N.; Wang, X.; Li, Z.; Gao, L.; Zhang, Y. Modified bentonite adsorption of organic pollutants of dye wastewater. Mater. Chem. Phys. 2017, 202, 266-276. [CrossRef]

31. Elwakeel, K.Z.; Guibal, E. Arsenic(V) sorption using chitosan $/ \mathrm{Cu}(\mathrm{OH})_{2}$ and chitosan/CuO composite sorbents. Carbohydr. Polym. 2015, 134, 190-204. [CrossRef]

32. Bao, S.; Tang, L.; Li, K.; Ning, P.; Peng, J.; Guo, H.; Zhu, T.; Liu, Y. Highly selective removal of Zn(II) ion from hot-dip galvanizing pickling waste with amino-functionalized $\mathrm{Fe}_{3} \mathrm{O}_{4} @ \mathrm{SiO}_{2}$ magnetic nano-adsorbent. J. Colloid Interface Sci. 2016, 462, 235-242. [CrossRef]

33. Lonappan, L.; Rouissi, T.; Brar, S.K.; Verma, M.; Surampalli, R.Y. An insight into the adsorption of diclofenac on different biochars: Mechanisms, surface chemistry, and thermodynamics. Bioresour. Technol. 2018, 249, 386-394. [CrossRef]

34. Nishiyama, Y.; Langan, P.; Chanzy, H. Crystal Structure and Hydrogen-Bonding System in Cellulose I $\beta$ from Synchrotron X-ray and Neutron Fiber Diffraction. J. Am. Chem. Soc. 2002, 124, 9074-9082. [CrossRef]

35. Gurina, D.; Surov, O.; Voronova, M.; Zakharov, A.; Kiselev, M. Water Effects on Molecular Adsorption of Poly(N-vinyl-2pyrrolidone) on Cellulose Nanocrystals Surfaces: Molecular Dynamics Simulations. Materials 2019, 12, 2155. [CrossRef]

36. Zhang, S.; Tang, C.; Xie, J.; Zhou, Q. Improvement of thermal stability of insulation paper cellulose by modified polysiloxane grafting. Appl. Phys. Lett. 2016, 109, 172902. [CrossRef]

37. Zhou, W.; Zhu, D.; Langdon, A.; Li, L.; Liao, S.; Tan, L. The structure characterization of cellulose xanthogenate derived from the straw of Eichhornia crassipes. Bioresour. Technol. 2009, 100, 5366-5369. [CrossRef]

38. French, A.D. Idealized powder diffraction patterns for cellulose polymorphs. Cellulose 2013, 21, 885-896. [CrossRef]

39. Liu, M.; Zhao, Z.; Yu, W. Citric acid modified wood membranes for efficient adsorption of tetracycline: Effect of alkali pretreatment concentration and adsorption mechanism. Chem. Eng. J. 2020, 393, 124748. [CrossRef]

40. Sun, S.; Yu, Q.; Li, M.; Zhao, H.; Wu, C. Preparation of coffee-shell activated carbon and its application for water vapor adsorption. Renew. Energy 2019, 142, 11-19. [CrossRef]

41. Chakraborty, A.; Sun, B. An adsorption isotherm equation for multi-types adsorption with thermodynamic correctness. Appl. Therm. Eng. 2014, 72, 190-199. [CrossRef]

42. Tiwari, D.; Bhunia, H.; Bajpai, P.K. Adsorption of $\mathrm{CO}_{2}$ on $\mathrm{KOH}$ activated, $\mathrm{N}$-enriched carbon derived from urea formaldehyde resin: Kinetics, isotherm and thermodynamic studies. Appl. Surf. Sci. 2018, 439, 760-771. [CrossRef]

43. Ahmed, M.; Islam, A.; Asif, M.; Hameed, B. Human hair-derived high surface area porous carbon material for the adsorption isotherm and kinetics of tetracycline antibiotics. Bioresour. Technol. 2017, 243, 778-784. [CrossRef]

44. Jiang, Z.; Hu, D. Molecular mechanism of anionic dyes adsorption on cationized rice husk cellulose from agricultural wastes. $J$. Mol. Liq. 2018, 276, 105-114. [CrossRef]

45. Li, Y.; Zhao, B.; Zhang, L.; Han, R. Biosorption of copper ion by natural and modified wheat straw in fixed-bed column. Desalination Water Treat. 2013, 51, 5735-5745. [CrossRef]

46. Mohamed, M.H.; Dolatkhah, A.; Aboumourad, T.; Dehabadi, L.; Wilson, L.D. Investigation of templated and supported polyaniline adsorbent materials. RSC Adv. 2014, 5, 6976-6984. [CrossRef] 
47. Nazir, M.A.; Yasar, A.; Bashir, M.A.; Siyal, S.H.; Najam, T.; Javed, M.S.; Ahmad, K.; Hussain, S.; Anjum, S.; Hussain, E.; et al. Quality assessment of the noncarbonated-bottled drinking water: Comparison of their treatment techniques. Int. J. Environ. Anal. Chem. 2020, 1-12. [CrossRef]

48. Ayub, A.; Irfan, A.; Raza, Z.A.; Abbas, M.; Muhammad, A.; Ahmad, K.; Munwar, A. Development of poly(1-vinylimidazole)chitosan composite sorbent under microwave irradiation for enhanced uptake of $\mathrm{Cd}(\mathrm{II})$ ions from aqueous media. Polym. Bull. 2021, 1-21. [CrossRef]

49. Ahmad, K.; Shah, H.-U.; Parveen, S.; Aziz, T.; Naseem, H.A.; Ashfaq, M.; Rauf, A. Metal Organic Framework (KIUB-MOF-1) as Efficient Adsorbent for Cationic and Anionic Dyes from Brackish Water. J. Mol. Struct. 2021, 1242, 130898. [CrossRef]

50. Shah, H.U.R.; Ahmad, K.; Naseem, H.A.; Parveen, S.; Ashfaq, M.; Rauf, A.; Aziz, T. Water stable graphene oxide metal-organic frameworks composite (ZIF-67@GO) for efficient removal of malachite green from water. Food Chem. Toxicol. 2021, 154, 112312. [CrossRef]

51. Naseem, H.A.; Aziz, T.; Shah, H.-U.; Ahmad, K.; Parveen, S.; Ashfaq, M. Rational synthesis and characterization of medicinal phenyl diazenyl-3-hydroxy-1h-inden-1-one azo derivatives and their metal complexes. J. Mol. Struct. 2020, 1227, 129574. [CrossRef]

52. Ahmad, K.; Nazir, M.A.; Qureshi, A.K.; Hussain, E.; Najam, T.; Javed, M.S.; Shah, S.S.A.; Tufail, M.K.; Hussain, S.; Khan, N.A.; et al. Engineering of Zirconium based metal-organic frameworks (Zr-MOFs) as efficient adsorbents. Mater. Sci. Eng. B 2020, 262, 114766. [CrossRef]

53. Stromer, B.S.; Woodbury, B.; Williams, C.F. Tylosin sorption to diatomaceous earth described by Langmuir isotherm and Freundlich Isotherm models. Chemosphere 2018, 193, 912-920. [CrossRef]

54. Bajaj, K.; Sakhuja, R. Benzotriazole: Much More Than Just Synthetic Heterocyclic Chemistry. zole: Much more than just synthetic heterocyclic chemistry. In The Chemistry of Benzotriazole Derivatives; Springer: Cham, Switzerland, 2015; pp. 235-283. [CrossRef]

55. Dong, R.Y.; Dong, Y.; Li, Q.; Wan, C. Ballistic-diffusive phonon transport in cellulose nanocrystals by ReaxFF molecular dynamics simulations. Int. J. Heat Mass Transf. 2019, 148, 119155. [CrossRef]

56. Široká, B.; Manian, A.P.; Noisternig, M.F.; Henniges, U.; Kostic, M.; Potthast, A.; Griesser, U.J.; Bechtold, T. Wash-dry cycle induced changes in low-ordered parts of regenerated cellulosic fibers. J. Appl. Polym. Sci. 2012, 126, E397-E408. [CrossRef]

57. Rajabi, M.; Mahanpoor, K.; Moradi, O. Preparation of PMMA/GO and PMMA/GO-Fe ${ }_{3} \mathrm{O}_{4}$ nanocomposites for malachite green dye adsorption: Kinetic and thermodynamic studies. Compos. Part B Eng. 2019, 167, 544-555. [CrossRef]

58. Zhang, X.; Yu, H.; Yang, H.; Wan, Y.; Hu, H.; Zhai, Z.; Qin, J. Graphene oxide caged in cellulose microbeads for removal of malachite green dye from aqueous solution. J. Colloid Interface Sci. 2014, 437, 277-282. [CrossRef]

59. Gharbani, P. Synthesis of polyaniline-tin(II)molybdophosphate nanocomposite and application of it in the removal of dyes from aqueous solutions. J. Mol. Liq. 2017, 242, 229-234. [CrossRef]

60. Altintig, E.; Onaran, M.; Sarı, A.; Altundag, H.; Tuzen, M. Preparation, characterization and evaluation of bio-based magnetic activated carbon for effective adsorption of malachite green from aqueous solution. Mater. Chem. Phys. 2018, 220, 313-321. [CrossRef]

61. Mashkoor, F.; Nasar, A. Preparation, characterization and adsorption studies of the chemically modified Luffa aegyptica peel as a potential adsorbent for the removal of malachite green from aqueous solution. J. Mol. Liq. 2018, 274, 315-327. [CrossRef]

62. Jiang, F.; Dinh, D.M.; Hsieh, Y.-L. Adsorption and desorption of cationic malachite green dye on cellulose nanofibril aerogels. Carbohydr. Polym. 2017, 173, 286-294. [CrossRef] [PubMed]

63. Arabkhani, P.; Asfaram, A. Development of a novel three-dimensional magnetic polymer aerogel as an efficient adsorbent for malachite green removal. J. Hazard. Mater. 2019, 384, 121394. [CrossRef] [PubMed]

64. Mobarak, M.; Mohamed, E.A.; Selim, A.Q.; Eissa, M.; Seliem, M.K. Experimental results and theoretical statistical modeling of malachite green adsorption onto MCM-41 silica/rice husk composite modified by beta radiation. J. Mol. Liq. 2018, 273 , 68-82. [CrossRef] 